\title{
Trace element behaviour at cold seeps and the potential export of dissolved iron to the ocean
}

\author{
Nolwenn Lemaitre ${ }^{\mathrm{a}, \mathrm{b}, \mathrm{c}}$, Germain Bayon ${ }^{\mathrm{a}, \text {, }}$, Hélène Ondréas ${ }^{\mathrm{a}}$, Jean-Claude Caprais ${ }^{\mathrm{d}}$, \\ Nicolas Freslon ${ }^{a, b}$, Claire Bollinger ${ }^{b, c}$, Marie-Laure Rouget ${ }^{b, c}$, Alexis de Prunelée ${ }^{a, b}$, Livio Ruffine ${ }^{a}$, \\ Karine Olu-Le Roy ${ }^{d}$, Géraldine Sarthou, ${ }^{\text {b, e }}$
}

\author{
a IFREMER, Unité de Recherche Géosciences Marines, F-29280 Plouzané, France \\ ${ }^{\mathrm{b}}$ UEB, Université Européenne de Bretagne, F-35000 Rennes, France \\ c IUEM, Institut Universitaire Européen de la Mer, Université de Bretagne Occidentale, CNRS UMS 3113, IUEM, \\ F-29280 Plouzané, France \\ d IFREMER, Unité de Recherche Etudes des Ecosystèmes Profonds, F-29280 Plouzané, France \\ e LEMAR, UMR 6539, CNRS, Université de Brest, IRD, Ifremer, IUEM, F-29280 Plouzané, France
}

*: Corresponding author : Nolwenn Lemaitre, tel.: +33 298224630 ; email address : gbayon@ifremer.fr

\begin{abstract}
:
Seawater samples were collected by submersible above methane seeps in the Gulf of Guinea (Regab and Baboon pockmarks) in order to investigate the behaviour of iron (Fe), manganese $(\mathrm{Mn})$ and rare earth elements (REE) during fluid seepage. Our aim was to determine whether cold seeps may represent potential sources of dissolved chemical species to the ocean. Dissolved $(<0.45 \mu \mathrm{m}$ filtered samples) and total dissolvable (unfiltered samples) concentrations were determined over $\sim 50 \mathrm{~m}$ long vertical transects above the seafloor and at various discrete locations within the pockmarks.
\end{abstract}

We show that substantial amounts of $\mathrm{Fe}$ and $\mathrm{Mn}$ are released into seawater during seepage of methane-rich fluids. $\mathrm{Mn}$ is exported almost quantitatively in the dissolved form (more than $90 \%$ of total $\mathrm{Mn}$; mean $\mathrm{Mn}_{\text {DISS }} \sim 12 \pm 11 \mathrm{nmol} / \mathrm{kg} \sim 12 \pm 11 \mathrm{nmol} / \mathrm{kg}$ ). Although a significant fraction of $\mathrm{Fe}$ is bound to particulate phases, the dissolved iron pool still accounts on average for approximately 20 percent of total iron flux at vent sites (mean $\mathrm{Fe}_{\text {DIss }} \sim 22 \pm 11 \mathrm{nmol} / \mathrm{kg} 22 \pm 11 \mathrm{nmol} / \mathrm{kg}$ ). This dissolved Fe fraction also appears to remain stable in the water column. In contrast, there was no evidence for any significant benthic fluxes of pore water REE associated with fluid seepage at the studied sites.

Overall, our results point towards distinct trace element behaviour during fluid seepage, with potential implications for the marine geochemical budget. The absence of any dissolved REE enrichments in bottom waters clearly indicates effective removal in sub-surface sediments. Most likely, precipitation of authigenic mineral phases at cold seeps (i.e. carbonates) represents a net sink for these elements. While $\mathrm{Mn}$ appears to behave near-conservatively during fluid seepage, the observed relative stability of dissolved $\mathrm{Fe}$ in the water column above seepage sites could be explained by complexation with strong organic ligands and/or the presence of Fe-bearing sulfide nanoparticles, as reported previously for submarine hydrothermal systems. Considering the ubiquitous occurrence of methane vents at ocean margins, cold seeps could represent a previously unsuspected source of dissolved Fe to the deep ocean. 


\section{Highlights}

Large amounts of dissolved $\mathrm{Fe}$ and $\mathrm{Mn}$ are released into seawater at methane seeps. Possible role of organic complexation or sulfide nanoparticles in stabilizing Fe. Cold seeps could represent an important source of dissolved Fe to the deep ocean. Precipitation of authigenic minerals leads to removal of REE in sediments.

Keywords: iron ; rare earth elements ; cold seeps ; seawater ; organic ligands ; iron-sulfide nanoparticles 


\section{1 - Introduction}

At ocean margins, the progressive accumulation of organic-rich sediments on the seafloor leads, with time and microbial degradation, to diagenetic remineralization of organic compounds and to methanogenesis (e.g. Martens and Berner, 1974). The migration of methane-rich fluids in sediment and subsequent release into bottom waters typically result in the formation of venting structures, such as pockmarks or mud volcanoes (e.g. Suess, 2010). These so-called 'cold' seeps are particularly common at margins, and hence could play an important role in the exchange processes between seawater and sediment, and in the distribution of trace elements in the water column.

Fluid venting at cold seeps sustains the development of abundant seafloor ecosystems, which rely on the chemosynthetic use of reduced chemical compounds (e.g. Sibuet et al., 1998). The main biogeochemical process in fluid venting areas is the anaerobic oxidation of methane (AOM). The AOM is generally coupled with sulfate reduction in anoxic sediments, which are both driven by microbial assemblages of archaea and bacteria, respectively (e.g. Boetius et al., 2000). This results in the release of bicarbonate ions and hydrogen sulfide into pore waters, which, in turn, often leads to precipitation of authigenic minerals, such as carbonates and sulfides (e.g. Aloisi et al., 2002).

Both microbial activity and carbonate precipitation represent a net sink for methane at cold seeps (e.g. Luff and Wallmann, 2003; Boetius and Wenzhofer, 2013). However, in highly active environments, excess methane can be expelled into bottom waters. Methane plumes can rise up to several kilometers through the water column, as inferred from direct $\mathrm{CH}_{4}$ measurements and acoustic investigations of gas flares at margins worldwide (Charlou et al., 2003; Charlou et al., 2004; Sauter et al., 2006; Greinert et al., 2006; Mastalerz et al., 2007; Solomon et al., 2009; Westbrook et al., 2009; Brothers et al., 2013; Kannberg et al., 2013). The emission of methane-rich fluids at the seafloor is also typically associated with high particulate contents, which can be detected using nephelometers and/or measurements of high concentrations of Fe and Mn in seawater (e.g. Charlou et al., 2004; Sauter et al., 2006; Bayon et al., 2011a). By analogy with submarine hydrothermal systems, it is generally assumed that the mixing of anoxic fluids with oxygen-rich bottom waters leads to the precipitation of Fe and Mn oxyhydroxides in methane plumes (Charlou et al., 2004; Bayon et al., 2011a). However, with the exception of barium (Kasten and Jorgensen, 2000; Dickens, 2001; Torres et al., 2002; Aloisi et al., 2004; Riedinger et al., 2006; McQuay et al., 2008; Kasten et al., 
2012; Griffith and Paytan, 2012), the behaviour of iron, manganese and other trace elements during fluid seepage remains largely unexplored. In particular, it is unknown whether cold seeps may represent, or not, a source of dissolved iron to seawater.

Most dissolved iron in seawater is complexed with natural organic ligands (e.g. Rue and Bruland, 1995; Laglera and van den Berg, 2009; Gledhill and Buck, 2012; Misumi et al., 2013). Iron-organic complexes are characterized by high stability constants in the marine environment, which prevents (or delays) precipitation and enhances dissolved $\mathrm{Fe}$ concentrations in seawater (e.g. Sander and Koschinsky, 2011; Gledhill and Buck, 2012). Over recent years, several studies have demonstrated the presence of Fe-binding organic complexes in hydrothermal fluids and plumes, with global implications for the global $\mathrm{Fe}$ budget (Sander et al., 2007 \& 2011, Bennett et al., 2008; Toner et al., 2009; Tagliabue et al., 2010; Wang et al., 2012; Hawkes et al., 2013; Saito et al., 2013). The hypothesis that reduced iron species could leak from hydrothermal vents was also suggested by speciation studies of plume particles, revealing the presence of non-sulfide iron(II) phases associated with carbonrich material (Statham et al., 2005; Toner et al., 2009; Toner et al., 2012). In addition, Febearing sulfide nanoparticles are also typically present within hydrothermal plumes (Yücel et al., 2011; Gartman et al., 2014). Because nanoparticulate sulfides are not retained onto filters with a $0.45 \mu \mathrm{m}$ or $0.22 \mu \mathrm{m}$ pore size filters, they have been shown to account for a significant fraction (as high as $25 \mathrm{wt} \%$ ) of the so-called 'dissolved' iron at hydrothermal vents (Yücel et al., 2011; Gartman et al., 2014). At present, the fate of these very fine sulfide particles within methane plumes is unknown, but they could possibly be transported over long distances in the deep ocean (Carazzo et al., 2013).

The main objective of this study was to investigate the behaviour of iron and manganese at cold seeps, and to assess the potential significance of fluid seepage to the global oceanic budget. The work presented here focused on methane seeps from the Gulf of Guinea, including the Regab pockmark, a well-studied highly active seepage site on the Congo margin (Ondréas et al., 2005). In addition to Fe and Mn, we also used the rare earth elements (REE), because their behaviour at cold seeps is presumably related to Fe and Mn cycling (Bayon et al., 2011). The REE also represent potentially interesting tracers of fluid seepage at margins, because they are generally highly enriched in pore waters relative to overlying bottom waters (Haley et al., 2004). A study conducted above methane seeps at the Niger delta margin suggested however that REE could be quantitatively scavenged during fluid emission, 
presumably due to scavenging onto Fe-Mn oxyhydroxide phases in sub-surface sediments (Bayon et al., 2011a).

\section{2 - Study area}

In the Gulf of Guinea, the Congo margin is the location of several active sites of venting fluid (Ondréas et al., 2005; Sahling et al., 2008; Pierre et al., 2012). The most studied site in this area is Regab, a giant pockmark of about $800 \mathrm{~m}$ wide, located at $3160 \mathrm{~m}$ depth near the Congo submarine canyon (Fig. 1). This canyon has been directly connected to the mouth of the Congo River, at least since the Quaternary period, thereby acting as a direct source-to-sink route for sediments from the continent to the deep sea basin (Babonneau et al., 2002). It delivers substantial amounts of organic-rich sediments to the entire Congo submarine system (Baudin et al., 2010). Regab was first explored during the Zaiango project (1998-2000), and was further investigated during subsequent cruises (e.g., Ondreas et al., 2005; Pop-Ristova et al., 2012). The source of methane-rich fluids at Regab is thought to derive from a buried palaeo-channel of the Congo River (Ondréas et al., 2005). Regab is characterized by intense methane seepage and the occurrence of gas hydrates, massive carbonate deposits, and abundant chemosynthetic communities at the seafloor (Ondréas et al., 2005; Charlou et al., 2004; Gay et al., 2006; Pierre and Fouquet, 2007; Olu-LeRoy et al., 2007; Olu et al., 2009; Marcon et al., 2014a; Duperron et al., 2014). Over recent years, several other active venting sites, known as the Kouilou pockmarks, have also been discovered on the northern Congo margin, about $100 \mathrm{~km}$ north of Regab (Sahling et al., 2008; Pierre et al., 2012). This includes the Baboon pockmark ( $3000 \mathrm{~m}$ depth), characterized like Regab by the occurrence of gas hydrate deposits, seafloor carbonate pavements, and intense methane seepage.

\section{3 - Materials and methods}

\subsection{Microbathymetric map, seafloor observations and sampling}

The seafloor photographs and microbathymetric data presented in this study were acquired via the Victor 6000 ROV (Remote Operated Vehicle) during the WACS expedition (2011) aboard R/V Pourquoi Pas? (chief scientist: K. Olu-Le Roy). The new microbathymetric data provide details of seafloor morphology at Regab with an unprecedented high-resolution (Marcon et 
al., 2014b). Seafloor submersible observations are superimposed onto the new microbathymetric map in Fig. 2. The central part of the pockmark is composed of several large clustered depressions (about $50 \mathrm{~m}$ wide), where the most active seepage sites are concentrated (Ondréas et al., 2005; Marcon et al., 2014b). This area is characterized by seafloor occurrence of gas hydrates and carbonate crusts, active gas plumes, and dense mussel (Mytilidae) and clam (Vesicomyidae) beds (Fig. 3a,b,c,d). The northern part of Regab also displays a rough topography with irregular outcrops of carbonate crusts serving as hard substrates for dense bushes of vestimentiferan (Escarpia southwardae) tubeworms (Fig. 3e). In contrast, the western and southern parts of the pockmark are mainly composed of bioturbated sediment riddled with small meter-wide holes. In this area, a few larger depressions (about $10 \mathrm{~m}$ wide) are often found in association with patches of clams (Vesicomyidae) and microbial mats related to reduced sediments (Fig. 3f).

Seawater samples were collected using the automated PEPS system, which allowed sampling of twelve individual acid-cleaned 2L plastic bags during each ROV dive (Table 1). At Regab, the seawater samples were taken along vertical profiles up to about $+60 \mathrm{~m}$ above the seafloor at three different stations: 1) a highly active site of gas venting in the center of the pockmark (hereafter referred to as the 'Bubble' site); 2) another active area in the eastern part of the pockmark (i.e. East Pockmark site), at about $300 \mathrm{~m}$ from the Bubble Site; and 3) a reference station (i.e. Reference site), also located eastwards at about $1 \mathrm{~km}$ away from the center of the pockmark (Fig. 2). These sampling sites were selected based on results from a previous ROV survey, during which bottom water samples were collected and further analysed for methane concentrations (Charlou et al., 2004; Fig. 2). The methane contents measured at these three sites were $\sim 130 \mu 1 / 1,17 \mu 1 / 1$ and $0.05 \mu 1 / 1$, respectively (Charlou et al., 2004; Table S1). While the bottom water sample at the reference site was characterized by much lower $\mathrm{CH}_{4}$ contents, this value was still significantly higher than typical deep water methane background levels in the Atlantic Ocean (6-8 nl/1; Lamontagne et al., 1973), suggesting that this location was also under the influence of methane plumes from Regab. During the WACS expedition, seawater was also collected at just a few centimeters above the seafloor within the pockmark, next to patches of vesicomyid clams, mussels (two sites) and microbial mats. At Baboon, samples were collected at $3 \mathrm{~m}$ above the seafloor during a ROV dive across the pockmark. All samples were filtered on board onto $<0.45 \mu \mathrm{m}$ cellulose filters within a few hours after collection. Both filtered and unfiltered samples were directly transferred into acid-cleaned 
HDPE Nalgene ${ }^{\circledR}$ bottles, and further acidified on board with twice sub-boiled nitric acid to $\mathrm{pH} \sim 2$.

\subsection{Chemical and analytical procedures}

The bottom water samples collected at Baboon and above the seafloor chemosynthetic habitats investigated at Regab were analysed for methane concentrations. On board, 5-ml seawater aliquots were conditioned into $10-\mathrm{ml}$ serum vials, poisoned with $20 \mu 1 \mathrm{HgCl}_{2}$, and stored at $4{ }^{\circ} \mathrm{C}$. Methane concentrations were then determined onshore by static headspace gas chromatography (Perichrom ${ }^{\circledR}$ Pr2100). The chemical preparations prior to trace element measurements were conducted back to the clean laboratory (ISO-6) at Brest. All experiments were made in polypropylene tubes cleaned with the following sequence: $5 \%$ nitric acid, milliQ 18.2M $\Omega$ water, $2 \%$ nitric acid twice sub-boiled and milli-Q 18.2M $\Omega$ water. Pipette tips used for the experiments underwent the same cleaning procedure. All measurements were made using mass spectrometry techniques at the Pôle Spectrométrie Océan (PSO, Brest).

Rare earth elements, Y, Fe, and Mn concentrations were determined by sector field ICPMS (Element2) after addition of mixed ${ }^{57} \mathrm{Fe}$-thulium (Tm) spike and double magnesium $\left(\mathrm{Mg}(\mathrm{OH})_{2}\right)$ co-precipitation (Wu, 2007; Freslon et al., 2011). The iron concentration of the spike was calibrated by inverse isotopic dilution using several certified reference geological materials (MGL-AND, BIR-1, BCR-1, HTB-1). The $\mathrm{Mg}(\mathrm{OH})_{2}$ co-precipitation was performed on carefully weighed seawater samples (about $25 \mathrm{ml}$ ) by adding ultra-pure ammonia (Optima, Fisher Scientist, VWR BDH Prolabo, 25\%). After two successive coprecipitations, the final $\mathrm{Mg}(\mathrm{OH})_{2}$ precipitate was cleaned and further dissolved in $2 \%$ Ultrex ${ }^{\circledR}$ II $\mathrm{HNO}_{3}$ prior to ICPMS analysis. Measured REE concentrations were corrected for oxide and hydroxide interferences (Barrat et al., 1996). Iron and Mn counts were measured in the medium resolution mode of the Element2 SF-ICPMS. Iron concentrations were determined by isotopic dilution, while the abundances for other elements (Mn, REE, Y) were calculated using the Tm addition method (Bayon et al., 2011b; Freslon et al., 2011).

Procedural blanks for all studied elements were determined using the same methods as for water samples, applied to a seawater sample depleted in trace elements by five successive magnesium co-precipitations. Total blank contributions for Fe $(1.4 \pm 0.5 \mathrm{ng}$; N=12; $1 \mathrm{SD})$ were always below $20 \%$ in our samples. Average blank contributions for all other elements 
were generally negligible. The accuracy and precision of our analyses were assessed using two certified reference materials (NASS-6 and CASS-5), and one in-house seawater standard (Concarneau Bay, Brittany, France). Replicate analyses of the two certified seawater standards gave accuracies better than 7\% for Fe and Mn compared to certified values (Table $\mathrm{S} 1$ ). The corresponding relative standard deviations (RSD\%) were lower than $33 \%$ for $\mathrm{Mn}$ and Fe (Table S2). For REE and Y, both accuracies (for CASS-5; Rousseau et al., 2013) and precisions were generally better than $8 \%$, with the exception of Yttrium (Y, RSD $<13 \%$ ), Lanthanum ( $\mathrm{La}, \mathrm{RSD}<13 \%$ ), and Cerium ( $\mathrm{Ce},<25 \%$ ). As will be discussed below, all studied samples were characterized by REE shape patterns typical of seawater and/or Fe-Mn oxyhydroxide phases. One unfiltered sample however (Bubble site $+5 \mathrm{~m}$; Table 2) displayed anomalously high La and Ce concentrations, perhaps due to contamination, and hence was discarded in the following discussion.

\section{4 - Results}

The bottom waters sampled above the seafloor habitat patches at Regab $(+0.1 \mathrm{~m})$ and at Baboon $(+3 \mathrm{~m})$ exhibit high $\mathrm{CH}_{4}$ concentrations, ranging between $\sim 32-132 \mu \mathrm{l} / 1$ and 10-70 $\mu 1 / 1$, respectively (Table S2). Vertical profiles for dissolved (filtered samples) and total dissolvable (unfiltered samples) element concentrations at the three studied Regab stations are shown in Fig. 4. The corresponding data are listed in Table 2 and Table 3. The Bubble station is characterized by marked enrichments of iron and manganese in unfiltered seawater samples (up to $\sim 400$ and $\sim 20 \mathrm{nmol} / \mathrm{kg}$, respectively), which are clearly related to emission of methanerich fluids in the central part of Regab (Fig. 2). An important feature is that bottom waters also retain elevated concentrations of both dissolved $\mathrm{Fe}$ and $\mathrm{Mn}$, at least as high as $+40 \mathrm{~m}$ above the seafloor (about $\sim 30-40$ and $\sim 12-20 \mathrm{nmol} / \mathrm{kg}$, respectively). Seafloor samples collected above chemosynthetic habitats at Regab and across the Baboon pockmark display similar concentration levels ( $\mathrm{Fe}_{\text {DISS }} \sim 7-34 \mathrm{nmol} / \mathrm{kg}$ and $\mathrm{Mn}_{\text {DISS }} \sim 3-47 \mathrm{nmol} / \mathrm{kg}$ ). In comparison, the bottom water column at the Reference site exhibits lower values, with $\mathrm{Fe}_{\mathrm{DISS}}$ $\sim 5-10 \mathrm{nmol} / \mathrm{kg}$ and $\mathrm{Mn}_{\text {DISS }} \sim 5-8 \mathrm{nmol} / \mathrm{kg}$ (when excluding the sample nearest to the seafloor, $\mathrm{Mn}_{\text {DISS }} \sim 19 \mathrm{nmol} / \mathrm{kg}$ ). Although this latter station is located at about $1 \mathrm{~km}$ away from the Regab center, it has to be noted however that these 'reference' $\mathrm{Fe}_{\text {DISS }}$ and $\mathrm{Mn}_{\text {DISS }}$ values are still much higher than typical open-ocean deep water values in the South Atlantic (i.e. $<0.7$ nmol/kg; Noble et al., 2012). 
Rare earth element concentrations in unfiltered samples are generally higher near the seafloor (up to TDNd $\sim 80 \mathrm{pmol} / \mathrm{kg}$ ). Measured dissolved REE concentrations range from e.g. $\mathrm{Nd}_{\text {DISS }}$ $\sim 20$ to $42 \mathrm{pmol} / \mathrm{kg}$. The lowest $\mathrm{Nd}_{\text {DISS }}$ concentrations were determined in the water column overlying the Bubble site (mean value of $\sim 21.6 \pm 1.6 \mathrm{pmol} / \mathrm{kg}$ ). In comparison, dissolved REE concentrations in the bottom water column at the Reference station are higher (mean $\mathrm{Nd}_{\text {DISS }} \sim 26 \pm 1 \mathrm{pmol} / \mathrm{kg}$ ). With one exception, all seawater samples from the reference site exhibit very similar seawater-like REE patterns (e.g. Elderfield and Greaves, 1982), showing a pronounced negative Ce-anomaly and a progressive enrichment from the light- (LREE) to the heavy-REE (HREE) (Fig. 5). In contrast, a few unfiltered samples from the Bubble Site $(+1 \mathrm{~m})$, the Reference Site $(+1 \mathrm{~m})$, and seafloor habitat patches display much higher REE concentrations and a distinctive shale-normalized REE pattern, with a less negative (or positive) Ce-anomaly and mid-REE (MREE) enrichment over HREE (Fig. 5).

\section{5 - Discussion}

\subsection{Evidence for a decoupling between REE and Fe}

The distribution patterns of rare earth elements provide useful information on both fluid sources and the origin of particulate phases at submarine hydrothermal vents and cold seeps (e.g. German et al., 1990; Sherrell et al., 1999; German et al., 2002; Edmonds and German, 2004; Bayon et al., 2011a). At the Reference site, the REE pattern shape of the unfiltered sample collected at $+1 \mathrm{~m}$ over the seafloor is characteristic of the Fe-Mn oxyhydroxide fraction that can be extracted from marine sediments by sequential leaching, including those from the Gulf of Guinea (Bayon et al., 2004; Bayon et al., 2011a). Considering that high TDFe and TDMn concentrations were also found in the same sample, this indicates that high particulate load is probably present in seawater at this location. By analogy, a similar conclusion can also be drawn from the REE pattern shapes determined for other unfiltered seawater samples at Baboon and over seafloor habitat patches and the Bubble vent site $(+1 \mathrm{~m})$ at Regab (Fig. 5). Such TDREE, Mn, Fe enrichments in bottom waters overlying active seepage sites are clearly diagnostic of sediment resuspension due to emission of gas-rich fluids at submarine vents, similar to what has been previously proposed (Charlou et al., 2004; Bayon et al., 2011a). On the Niger Delta margin, this is nicely illustrated by the positive correlation displayed by $\mathrm{TDFe}$ and $\mathrm{TDNd}$ in seawater samples collected above active pockmarks and mud volcanoes (Fig. 6). 
Interestingly, however, Fe and REE appear to behave slightly differently in the water column at the Regab and Baboon pockmarks (Fig. 6). While bottom waters at the Bubble site and Baboon display a large range of TDFe values (between $\sim 70$ to $600 \mathrm{nmol} / \mathrm{kg}$ ), generally much higher than those for the Reference and East Pockmark stations (between $\sim 30$ to $60 \mathrm{nmol} / \mathrm{kg}$ ), TDNd yields similar levels of concentrations in most samples. This is clearly shown on the TDNd versus TDFe plot (Fig. 6), suggesting that Fe and REE are decoupled during fluid venting at Regab.

One possible explanation accounting for the observed decoupling between Fe and REE would be that TDFe is not solely controlled by Fe-oxyhydroxide phases in methane plumes. At hydrothermal vents, the iron budget in plume particles is dominated by $\mathrm{Fe}$ oxyhydroxide/oxide phases, but also by Fe-sulfide minerals (e.g. Toner et al., 2009; Breier et al., 2012). Iron speciation measurements have shown that oxidized iron(III) and sulfides could account for about $10 \mathrm{~mol} \%$ and $\sim 60-70 \mathrm{~mol} \%$ of total iron in hydrothermal plume particles, respectively (Toner et al., 2009; Toner et al., 2012). Iron sulfides precipitate within the buoyant plumes, immediately after hydrothermal discharge into the water column. Then, the increase of $\mathrm{pH}$ and dissolved $\mathrm{O}_{2}$ contents in the non-buoyant plume usually leads to precipitation of the remaining (or most of it) dissolved iron as Fe-oxyhydroxides. Like hydrothermal systems, cold seeps are also generally characterized by high sulfide concentrations (up to $\sim 10 \mathrm{mM}$ in pore waters at Regab; Pop-Ristova et al., 2012). It seems unlikely that acidification to $\mathrm{pH} \sim 2$ would achieve complete dissolution of Fe-sulfide phases in our unfiltered samples. However, because REE are strongly depleted in sulfide minerals (e.g. Tachikawa et al., 2013), only partial dissolution of particulate Fe-sulfide phases in bottom waters at the Bubble site could perhaps explain the observed decoupling between $\mathrm{Fe}$ and REE. The distinct TDFe vs. TDNd trends that can be inferred from the Regab and Baboon data in Fig. 6 could hence be possibly explained by a combination of both sulfide and oxyhydroxide precipitation. At the Niger seeps, seawater samples were collected by a $\mathrm{CTD} /$ Rosette system operated from the deck, suggesting that they may not be representative of the methane plumes expelled immediately above venting sites. This is also suggested by the fact that the Niger samples are characterized by relatively low methane contents (i.e. about one order of magnitude lower) compared to those collected by ROV above the Congo seeps. The absence of any sulfide enrichment in the Niger samples could hence suggest that these particles are not efficiently transported over long distances in deep waters. 
In addition, removal of substantial amounts of dissolved REE from pore waters before seafloor venting of methane-rich fluids could also potentially contribute to the observed decoupling between $\mathrm{Fe}$ and REE at Regab. At cold seeps, precipitation of authigenic carbonate minerals (e.g. aragonite, high-Mg calcite) commonly takes place in anoxic subsurface sediments or bottom waters, in relation to anaerobic oxidation of methane (e.g. Aloisi et al., 2002; Bayon et al., 2013). The high REE contents determined in methane-derived carbonates suggest that carbonate precipitation probably represents an important sink for REE in marine sediments (Himmler et al., 2010; Rongemaille et al., 2011; Feng et al., 2013). This has been recently confirmed in a study reporting pore water REE data at Hydrate Ridge (NE Pacific Ocean), which showed that REE were almost quantitatively depleted at the sulfatemethane interface (Himmler et al., 2013). In areas characterized by high methane fluxes, such as the central part of Regab (Pop-Ristova et al., 2012), both AOM and carbonate precipitation takes place at only a few centimeters below the seafloor. As a consequence, intense carbonate precipitation could possibly influence, at least locally, REE distribution in bottom waters, thereby perhaps explaining the slightly lower dissolved REE concentrations at the Bubble site (mean $\mathrm{Nd}_{\text {DISS }} \sim 21.6 \pm 1.6 \mathrm{pmol} / \mathrm{kg}$ ) compared to the Reference station (mean $\sim 26 \pm 1$ $\mathrm{pmol} / \mathrm{kg})$.

Overall, our data for unfiltered seawater samples hence suggest that REE and Fe are decoupled during fluid venting at cold seeps, due to the combined precipitation of both REErich Fe-oxyhydroxide and REE-poor Fe-sulfide phases in the methane plumes, but also possibly in sub-surface sediments, during precipitation of authigenic carbonate deposits.

\subsection{The distribution of dissolved Fe and Mn in the water column}

The observed positive correlations between $\mathrm{CH}_{4}$, and $\mathrm{Fe}_{\text {DISS }}$ and $\mathrm{Mn}_{\text {DISS }}$ concentrations in the studied seawater samples clearly show that fluid seepage at Regab and Baboon is accompanied with substantial release of dissolved iron and manganese species (Fig. 7). Over the last decades, a large amount of work has been conducted on submarine hydrothermal plumes, which provides useful background information for predicting trace element behaviour at cold seeps. Dissolved $\mathrm{Mn}$ is known to oxidize very slowly in hydrothermal plumes, exhibiting near-conservative behaviour on time scales of days to weeks (e.g. Cowen et al., 1990). At the Congo seeps, both unfiltered and filtered seawater samples generally display very similar Mn concentrations (within 20\% in most cases), including above the active 
Bubble vent site. This indicates that $\mathrm{Mn}$ is mainly present in soluble form, remaining stable at least over the time scale of the age of the plumes sampled at Regab. At the Bubble site, the highest dissolved $\mathrm{Mn}$ concentrations $\left(\mathrm{Mn}_{\text {DISS }} \sim 21 \mathrm{nmol} / \mathrm{kg}\right)$ were determined at about $+40 \mathrm{~m}$ above the seafloor (Fig. 4), possibly indicating the presence of another discrete plume in the water column. This result would be in agreement with evidence from the $\mathrm{CH}_{4}$ distribution map above the seafloor at Regab (Charlou et al., 2004; Fig. 5), which clearly suggests that distinct methane plumes may co-exist in the water column, especially in the central part of the pockmark.

In contrast to $\mathrm{Mn}$, iron oxidation rates reported at hydrothermal sites are much higher (Millero et al., 1987; Millero et al., 1998; Field and Sherrell, 2000; Statham et al., 2005). Dissolved iron generally oxidizes within minutes or hours in seawater and non-buoyant plumes, depending on bottom water chemistry $\left(\mathrm{pH}, \mathrm{O}_{2}\right.$ and $\mathrm{H}_{2} \mathrm{O}_{2}$ contents; Gonzalez-Davila et al., 2006; Sarthou et al., 2011). The same process probably explains the large differences

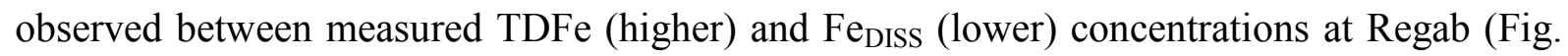
4; Table 2), implying that a substantial amount of released iron is associated with particulate oxyhydroxide and/or sulfide phases (i.e. see section 5.2). At the active Bubble site, however, the dissolved Fe pool accounts for a non-negligible $22 \pm 7 \%$ of total iron in the water column. Interestingly, while TDFe values markedly decrease from seafloor to $+20 \mathrm{~m}$ height (from 400 to $100 \mathrm{nmol} / \mathrm{kg}$; Table 2), dissolved Fe concentrations remain at relatively similar levels $\left(\mathrm{Fe}_{\text {DISS }} \sim 33 \pm 5 \mathrm{nmol} / \mathrm{kg}\right.$ ). Moreover, considering that the plume sampled at $+40 \mathrm{~m}$ is older than near-seafloor fluids collected just above the vent, another striking feature of our data is evidence that seawater samples collected at both $+1 \mathrm{~m}$ and $+40 \mathrm{~m}$ exhibit very similar dissolved $\mathrm{Mn} / \mathrm{Fe}$ ratio $(\sim 0.4-0.6)$.

At Regab, the theoretical dissolved Fe(II) oxidation rate predicted using the approach developed by Millero et al. (1987) gives an oxidation half-life for iron of about $40 \mathrm{~min}$. This calculation is made using well-constrained temperature $\left(\mathrm{T}=2.4^{\circ} \mathrm{C}\right), \mathrm{pH}(7.8)$, and $\mathrm{O}_{2}(240$ $\mathrm{mM}$ ) bottom water conditions (Charlou et al., 2004; Olu et al., 2007). In agreement with the relatively high methane concentration measured at the Reference site (46 nl/1; Charlou et al.,

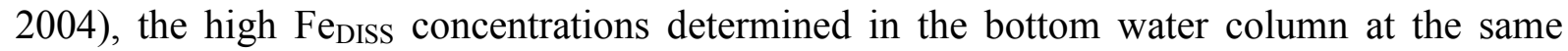
location suggest that this site is still under the influence of Regab methane plumes. The residual deep currents in the Regab area, averaged over a one-year period, are oriented eastward with a mean speed of $4.1 \mathrm{~cm} / \mathrm{s}$ (Vangrieshiem et al., 2009), and hence would be likely to transport methane-rich fluids from Regab to the Reference site. As opposed to 
hydrothermal vents, fluid escape at cold seeps is not restricted to localized discharge sites only, so that it is difficult to infer the source of Fe and Mn at the Reference station. However, considering the distance between the Regab center and the Reference station (about $1 \mathrm{~km}$ ), a minimum advection time of about 7 hours can be calculated, which is long compared to the theoretical Fe oxidation half-life ( $40 \mathrm{~min})$. Using this theoretical value, the measured dissolved Fe concentrations at the Reference site would correspond to an advection time of 45 min, which would hence require an unlikely bottom current speed of $\sim 37 \mathrm{~cm} / \mathrm{s}$. Therefore, and although a substantial amount of iron emitted at the Congo seeps appears to be linked to particulate phases, all the above consideration suggests that $\mathrm{Fe}(\mathrm{II})$ oxidation rates in bottom waters are longer than theoretical rates. This implies that a dissolved iron fraction probably remains relatively stable above the pockmark after emission into the water column, which is then likely to be further transported away with bottom currents.

\subsection{The stabilization of dissolved iron at cold seeps - possible implication for the global iron budget in the ocean}

As discussed above, a substantial fraction of the dissolved iron released at the Baboon and Regab pockmarks is probably stabilized in bottom waters. By analogy with submarine hydrothermal vents, the high concentrations and apparent stability of dissolved iron at the Congo seeps could be explained by complexation onto organic ligands (e.g. Bennett et al., 2008; Toner et al., 2009; Sander and Koschinsky, 2011) and/or the presence of sulfide nanoparticles (Yücel et al., 2011; Gartman et al., 2014).

On margins, methane seepage and associated biogeochemical processes are intimately linked to organic matter recycling. In sub-surface sediments, early diagenetic processes typically release hydrolysable compounds into pore waters, such as amino acids and fatty acids (e.g. Chester and Jickells, 2012). Under anoxic conditions, further degradation of organic compounds can also cause substantial enrichments in dissolved humic substances (Wallmann et al., 2008). Because high rates of organic matter deposition occur typically on ocean margins, cold seeps could clearly represent a plentiful supply of metal-binding organic ligands. At submarine hydrothermal systems, the amount of stabilized Fe(II) and Fe(III) is expected to be controlled to some extent by the availability of dissolved organic ligands in methane plumes (e.g. Bennett et al., 2008). Considering the eventuality that methane-rich fluids at cold seeps may be more enriched in organic ligands than their analogs from mid- 
ocean ridges, this would also imply that they may have the capacity to sustain higher amounts of organically-bound dissolved Fe.

Continental margins had already been identified as important sources of dissolved iron to seawater, especially at oxygen minimum zones (Bruland et al., 2005; Noble et al., 2012). Elrod et al. (2004) even argued that the input of dissolved Fe from continental shelves could be as significant as the global iron input from aerosols. The present study suggests for the first time that methane venting at margins worldwide could also represent a source of dissolved Fe to seawater. To the best of our knowledge, there are unfortunately no other published data for dissolved iron and ligand concentrations in seawater at cold seeps that would enable us to quantify the contribution of cold seep iron to the global ocean budget. Based on our results, a first tentative estimate may be derived using the correlation observed between $\mathrm{CH}_{4}$ and dissolved $\mathrm{Fe}$ concentrations at the Congo seeps. The latest global estimate of methane efflux from submarine seeps to the overlying ocean is about $0.02 \mathrm{Gt}$ of carbon annually (Boetius and Wenzhöfer, 2013), which corresponds to the export of $\sim 2.2 \times 10^{12}$ moles of $\mathrm{CH}_{4}$ per year. This estimate is based on the presumption that a few tens of thousands of colds eeps are active at ocean margins worldwide (Boetius and Wenzhöfer, 2013). Assuming that a simple linear regression $\left(\left[\mathrm{Fe}_{\text {DISS }}\right]=0.0038 \times\left[\mathrm{CH}_{4}\right]\right.$; Fig. 7$)$ characterized the global relationship between $\mathrm{CH}_{4}$ and $\mathrm{Fe}_{\text {DISS }}$ emitted at seeps, we can calculate an annual dissolved iron flux of $\sim 8.4 \times 10^{9}$ moles. Of course, a substantial fraction of this estimated dissolved iron flux probably includes inorganic colloids and nano-sulfide particles that are not retained onto $0.45 \mu \mathrm{m}$ or $0.2 \mu \mathrm{m}$ filters, but would remain in the so-called dissolved phase for presumably a limited time only. At hydrothermal vents, about $30 \%$ of the total dissolved iron in plumes is bound to ligand phases and is truly available as a labile form to the deep ocean (Hawkes et al., 2013). Assuming that a similar percentage also applies to cold seep settings, we can estimate a dissolved iron flux of about $2.5 \times 10^{9}$ moles per year. While this firstestimate value should be taken with great caution, as it is probably associated with large uncertainty, it would be roughly similar to the dissolved iron inputs calculated for hydrothermal vents (from $\sim 3 \times 10^{8}$ to $1.5 \times 10^{9} \mathrm{~mol} / \mathrm{yr}$; Bennett et al., 2008; Tagliabue et al., 2010; Carazzo et al., 2013). This would imply that cold seeps, like submarine hydrothermal systems, potentially represent a substantial source of dissolved iron to the deep ocean. 
The data presented in this study confirm that precipitation of authigenic minerals probably represents a net sink for rare earth elements at seeps from the Congo margin. The formation of carbonate crusts/concretions in sub-surface sediments most likely prevents emission of dissolved $\mathrm{REE}$ and $\mathrm{Ba}$ into the overlying water column. In contrast, we show for the first time that substantial amounts of dissolved iron and manganese can be released into bottom waters at methane seeps. A significant fraction of $\mathrm{Fe}$ within methane plumes is present in the particulate fraction, probably in association with both Fe-Mn oxyhydroxides and sulfide mineral phases. Importantly, the dissolved Fe fraction released at vent sites appears to remain relatively stable in the water column, due possibly to iron complexation with strong organic which prevents Fe co-precipitation into mineral phases. To some extent, the presence of Febearing sulfide nanoparticulates in methane plumes could also account for the high concentrations and apparent stability of dissolved iron in bottom waters. These results suggest that seepage of methane-rich fluids at margins could be accompanied by substantial export of dissolved Fe to seawater, with possible implications for the global dissolved iron budget in the deep-ocean. To test these hypotheses, future studies should aim at characterizing iron speciation in methane plumes on ocean margins, and further quantify dissolved Fe fluxes at cold seeps.

\section{Acknowledgements}

We thank the Captain, the crews and all scientific participants onboard the R/V Pourquoi Pas? during the WACS expedition. In particular, C. Le Gall is warmly thanked for assistance at sea for handling the PEPS seawater sampling system. We also acknowledge J. Etoubleau, D. Birot, and Y. Germain for assistance in the laboratory; and A.-S Alix and M. Guillou for their help in GIS at IFREMER. Finally, the editor, Gideon Henderson, and four anonymous reviewers are greatly acknowledged for providing thorough and constructive reviews, which significantly improved an earlier version of this manuscript. This study was funded by IFREMER. 


\section{References}

Aloisi, G., Bouloubassi, I., Heijs, S.K., Pancost, R.D., Pierre, C., Damste, J.S.S., Gottschal, J.C., Forney, L.J., Rouchy, J.M., 2002. CH4-consuming microorganisms and the formation of carbonate crusts at cold seeps. Earth Planet. Sci. Lett. 203, 195-203.

Aloisi, G., Wallmann, K., Bollwerk, S.M., Derkachev, A., Bohrmann, G., Suess, E., 2004. The effect of dissolved barium on biogeochemical processes at cold seeps. Geochim. Cosmochim. Acta 68, 1735-1748.

Babonneau, N., Savoye, B., Cremer, M., Klein, B., 2002. Morphology and architecture of the present canyon and channel system of the Zaire deep-sea fan. Mar. Petrol. Geol. 19, 445467.

Barrat, J.A., Keller, F., Amosse, J., Taylor, R.N., Nesbitt, R.W., Hirata, T., 1996. Determination of rare earth elements in sixteen silicate reference samples by ICP-MS after Tm addition and ion exchange separation. Geostand. Newslett. 20, 133-139.

Baudin, F., Disnar, J.R., Martinez, P., Dennielou, B., 2010. Distribution of the organic matter in the channel-levees systems of the Congo mud-rich deep-sea fan (West Africa): Implication for deep offshore petroleum source rocks and global carbon cycle. Mar. Petrol. Geol. 27, 995-1010.

Bayon, G., German, C.R., Burton, K.W., Nesbitt, R.W., Rogers, N., 2004. Sedimentary FeMn oxyhydroxides as paleoceanographic archives and the role of aeolian flux in regulating oceanic dissolved REE. Earth Planet. Sci. Lett. 224, 477-492.

Bayon, G., Birot, D., Ruffine, L., Caprais, J.C., Ponzevera, E., Bollinger, C., Donval, J.P., Charlou, J.L., Voisset, M., Grimaud, S., 2011a. Evidence for intense REE scavenging at cold seeps from the Niger Delta margin. Earth Planet. Sci. Lett. 312, 443-452.

Bayon, G., Birot, D., Bollinger, C., Barrat, J.A., 2011b. Multi-Element Determination of trace elements in natural water reference materials by ICP-SFMS after Tm Addition and iron co-precipitation. Geostand. Geoanalytical Res. 35, 145-153.

Bayon, G., Dupré S., Ponzevera, E., Etoubleau, J., Chéron, S., Pierre, C., Mascle, J., Boetius, A., de Lange G., 2013. Formation of carbonate chimneys in the Mediterranean Sea linked to deep-water oxygen depletion. Nat. Geosci. 6, 755-760. 
Bennett, S.A., Achterberg, E.P., Connelly, D.P., Statham, P.J., Fones, G.R., German, C.R., 2008. The distribution and stabilisation of dissolved Fe in deep-sea hydrothermal plumes. Earth Planet. Sci. Lett. 270, 157-167.

Boetius, A., Wenzhöfer, F., 2013. Seafloor oxygen consumption fuelled by methane from cold seeps. Nat. Geosci. 6, 725-734.

Boetius, A., Ravenschlag, K., Schubert, C.J., Rickert, D., Widdel, F., Gieseke, A., Amann, R., Jorgensen, B.B., Witte, U., Pfannkuche, O., 2000. A marine microbial consortium apparently mediating anaerobic oxidation of methane. Nature 407, 623-626.

Breier, J.A., Toner, B.M., Fakra, S.C., Marcus, M.A., White, S.N., Thurnherr, A.M., German, C.R., 2012. Sulfur, sulfides, oxides and organic matter aggregated in submarine hydrothermal plumes at 9 degrees 50 ' N East Pacific Rise. Geochim. Cosmochim. Acta $88,216-236$.

Brothers, L.L., Van Dover, C.L., German, C.R., Kaiser, C.L., Yoerger, D.R., Ruppel, C.D., Lobecker, E., Skarke, A.D., Wagner, J.K.S., 2013. Evidence for extensive methane venting on the southeastern U.S. Atlantic margin. Geology 41, 807-810.

Bruland, K.W., Rue, E.L., Smith, G.J., DiTullio, G.R., 2005. Iron, macronutrients and diatom blooms in the Peru upwelling regime: brown and blue waters of Peru. Mar. Chem. 93, 81103.

Carazzo, G., Jellinek, A.M., Turchyn, A.V., 2013. The remarkable longevity of submarine plumes: Implications for the hydrothermal inut of iron to the deep-ocean. Earth Planet. Sci. Lett. 382, 66-76.

Charlou, J.L., Donval, J.P., Zitter, T., Roy, N., Jean-Baptiste, P., Foucher, J.P., (Foucher, JP); Woodside, J., 2003. Evidence of methane venting and geochemistry of brines on mud volcanoes of the eastern Mediterranean Sea. Deep-Sea Res. I 8, 941-958.

Charlou, J.L., Donval, J.P., Fouquet, Y., Ondreas, H., Knoery, J., Cochonat, P., Levache, D., Poirier, Y., Jean-Baptiste, P., Fourre, E., Chazallon, B., Party, Z.L.S., 2004. Physical and chemical characterization of gas hydrates and associated methane plumes in the CongoAngola Basin. Chem. Geol. 205, 405-425. 
Chester, R.R., Jickells, T., 2012. Marine Geochemistry, $3^{\text {rd }}$ Edition. Wiley-Blackwell, Oxford, 420pp.

Cowen, J.P., Massoth, G.J., Feely, R.A., 1990. Scavenging rates of dissolved manganese in a hydrothermal vent plume. Deep-Sea Res. A 37, 1619-1637.

Dickens, G.R., 2001. Sulfate profiles and barium fronts in sediment on the Blake Ridge: Present and past methane fluxes through a large gas hydrate reservoir. Geochim. Cosmochim. Acta 65, 529-543.

Duperron, S., Gaudron, S.M., Lemaitre, N., Bayon, G. (2014) Biogeochemical investigation of the cold seep tubeworm Escarpia southwardae (Annelida: Siboglinidae): symbiosis and trace element composition of the tube. Deep-Sea Res. I 90, 105-114.

Edmonds, H.N., German, C.R., 2004. Particle geochemistry in the Rainbow hydrothermal plume, Mid-Atlantic Ridge. Geochim. Cosmochim. Acta 68, 759-772.

Elderfield, H., Greaves, M.J., 1982. The rare-earth elements in sea-water. Nature 296, 214219.

Elrod, V.A., Berelson, W.M., Coale, K.H., Johnson, K.S., 2004. The flux of iron from continental shelf sediments: A missing source for global budgets. Geophys. Res. Lett. 31, L12307, doi: 10.1029/2004GL020216.

Falkner, K.K., Klinkhammer, G.P., Bowers, T.S., Todd, J.F., Lewis, B.L., Landing, W.M., Edmond, J.M., 1993. The behaviour of barium in anoxic marine waters. Geochim. Cosmochim. Acta 57, 537-554.

Feng, D., Lin, Z.J., Bian, Y.Y., Chen, D.F., Peckmann, J., Bohrmann, G., Roberts, H.H., 2013. Rare earth elements of seep carbonates: Indication for redox variations and microbiological processes at modern seep sites. J. Asian Earth Sci. 65, 27-33.

Field, M.P., Sherrell, R.M., 2000. Dissolved and particulate Fe in a hydrothermal plume at 9 degrees $45^{\prime}$ N, East Pacific Rise: Slow Fe (II) oxidation kinetics in Pacific plumes. Geochim. Cosmochim. Acta 64, 619-628.

Freslon, N., Bayon, G., Birot, D., Bollinger, C., Barrat, J.A., 2011. Determination of rare earth elements and other trace elements ( $\mathrm{Y}, \mathrm{Mn}, \mathrm{Co}, \mathrm{Cr})$ in seawater using Tm addition and $\mathrm{Mg}(\mathrm{OH})(2)$ co-precipitation. Talanta 85, 582-587. 
Gartman, A., Findlay, A.J., Luther III, G.W., 2014. Nanoparticulate pyrite and other nanoparticles are a widespread component of hydrothermal vent black smoker emissions. Chem. Geol. 366, 32-41.

Gay, A., Lopez, M., Ondreas, H., Charlou, J.L., Sermondadaz, G., Cochonat, P., 2006. Seafloor facies related to upward methane flux within a Giant Pockmark of the Lower Congo Basin. Mar. Geol. 226, 81-95.

German, C.R., Klinkhammer, G.P., Edmond, J.M., Mitra, A., Elderfield, H., 1990. Hydrothermal scavenging of rare-earth elements in the ocean. Nature 345, 516-518.

German, C.R., Colley, S., Palmer, M.R., Khripounoff, A., Klinkhammer, G.P., 2002. Hydrothermal plume-particle fluxes at 13 degrees $\mathrm{N}$ on the East Pacific Rise. Deep-Sea Res. I 49, 1921-1940.

Gledhill, M., Buck, K.N., 2012. The organic complexation of iron in the marine environment: A review. Frontiers in Microbiology 3, 1-17, doi: 10.3389/fmicb.2012.00069.

González-Dávila, M., Santana-Casiano, J.M., Millero, F.J., 2006. Competition between O2 and $\mathrm{H} 2 \mathrm{O} 2$ in the oxidation of Fe(II) in natural waters, J. Sol. Chem. 35, 95-111.

Greinert, J., Artemov, Y., Egorov, V., De Batist, M., McGinnis, D., 2006. 1300-m-high rising bubbles from mud volcanoes at 2080m in the Black Sea: Hydroacoustic characteristics and temporal variability. Earth Planet. Sci. Lett. 244, 1-15.

Griffith, E.M., Paytan, A., 2012. Barite in the ocean - occurrence, geochemistry and palaeoceanographic applications. Sedimentology 59, 1817-1835.

Haley, B.A., Klinkhammer, G.P., McManus, J., 2004. Rare earth elements in pore waters of marine sediments. Geochim. Cosmochim. Acta 68, 1265-1279.

Hawkes, J.A., Connelly, D.P., Gledhill, M., Achterberg, E.P., 2013. The stabilization and transportation of dissolved iron from high temperature hydrothermal vent systems. Earth Planet. Sci. Lett. 375, 280-290.

Himmler, T., Bach, W., Bohrmann, G., Peckmann, J., 2010. Rare earth elements in authigenic methane-seep carbonates as tracers for fluid composition during early diagenesis. Chem. Geol. 277, 126-136. 
Himmler, T., Haley, B.A., Torres, M.E., Klinkhammer, G.P., Bohrmann, G., Peckmann, J., 2013. Rare earth element geochemistry in cold-seep pore waters of Hydrate Ridge, northeast Pacific Ocean. Geo-Mar. Lett. 33, 369-379.

Kannberg, P.K., Trehu, A.M., Pierce, S.D., Paull, C.K., Caress, D.W., 2013. Temporal variation of methane flares in the ocean above Hydrate Ridge, Oregon. Earth Planet. Sci. Lett. 368, 33-42.

Kasten, S., Jorgensen, B.B., 2000. Sulfate Reduction in Marine Sediments, in: Schulz, H.D., Zabel, M. (Eds.), Marine Geochemistry. Springer, New York, pp. 263-282.

Kasten, S., Nothen, K., Hensen, C., Spiess, V., Blumenberg, M., Schneider, R.R., 2012. Gas hydrate decomposition recorded by authigenic barite at pockmark sites of the northern Congo Fan. Geo-Mar. Lett. 32, 515-524.

Laglera, L.M., van den Berg, C.M.G., 2009. Evidence for geochemical control of iron by humic substances in seawater. Limnol. Oceanol. 54, 610-619.

Lamontagne, R.A. et al., 1973. Methane concentrations in various marine environments. J. Geophys. Res. 78, 5317-5324.

Luff, R., Wallmann, K., 2003. Fluid flow, methane fluxes, carbonate precipitation and biogeochemical turnover in gas hydrate-bearing sediments at Hydrate Ridge, Cascadia Margin: Numerical modeling and mass balances. Geochim. Cosmochim. Acta 67, 34033421.

Marcon, Y., Sahling, H., Allais, A.G., Bohrmann, G., Olu, K., 2014a. Distribution and temporal variation of mega-fauna at the Regab pockmark (Northern Congo Fan), based on a comparison of videomosaics and geographic information systems analyses. Mar. Ecol., in press, doi:10.1111/maec.12056.

Marcon, Y., Ondreas, H., Sahling, H., Bohrmann, G., Olu, K., 2014b. Fluid flow regimes and growth of a giant pockmark. Geology, in press, doi:10.1130/G34801.1.

Martens, C.S., Berner, R.A., 1974. Methane production in the interstitial waters of sulfate depleted marine sediments. Science 185, 1167-1169. 
Mastalerz, V., de Lange, G.J., Dahlmann, A., Feseker, T., 2007. Active venting at the Isis mud volcano, offshore Egypt: Origin and migration of hydrocarbons. Chem. Geol. 246, 87-106.

McQuay, E.L., Torres, M.E., Collier, R.W., Huh, C.A., McManus, J., 2008. Contribution of cold seep barite to the barium geochemical budget of a marginal basin. Deep-Sea Res. I $55,801-811$.

Millero, F.J., Sotolongo, S., Izaguirre, M., 1987. The oxidation kinetics of Fe(II) in seawater. Geochim. Cosmochim. Acta 51, 793-801.

Millero, F.J., 1998. Solubility of Fe(III) in seawater. Earth Planet. Sci. Lett. 154, 323-329.

Misumi, K., Lindsay, K., Moore, J.K., Doney, S.C., Tsumune, D., Yoshida, Y., 2013. Humic substances may control dissolved iron distributions in the global ocean: Implications from numerical simulations. Global Biogeochem. Cycles 27, 450-462.

Noble, A.E., Lamborg, C.H., Ohnemus, D.C., Lam, P.J., Goepfert, T.J., Measures, C.I., Frame, C.H., Casciotti, K.L., DiTullio, G.R., Jennings, J., Saito, M.A., 2012. Basin-scale inputs of cobalt, iron, and manganese from the Benguela-Angola front to the South Atlantic Ocean. Limnol. Oceanol. 57, 989-1010.

Olu, K., Caprais, J.C., Galeron, J., Causse, R., von Cosel, R., Budzinski, H., Le Menach, K., Le Roux, C., Levache, D., Khripounoff, A., Sibuet, M., 2009. Influence of seep emission on the non-symbiont-bearing fauna and vagrant species at an active giant pockmark in the Gulf of Guinea (Congo-Angola margin). Deep-Sea Res. I 56, 2380-2393.

Olu-Le Roy, K., Caprais, J.C., Fifis, A., Fabri, M.C., Galéron, J., Budzinsky, H., Le Ménach, K., Khripounoff, A., Ondréas, H., Sibuet, M., 2007. Cold-seep assemblages on a giant pockmark off West Africa: spatial patterns and environmental control. Mar. Ecol. 28, 115-130.

Ondreas, H., Olu, K., Fouquet, Y., Charlou, J.L., Gay, A., Dennielou, B., Donval, J.P., Fifis, A., Nadalig, T., Cochonat, P., Cauquil, E., Bourillet, J.F., Le Moigne, M., Sibuet, M., 2005. ROV study of a giant pockmark on the Gabon continental margin. Geo-Mar. Lett. 25, 281-292. 
Pierre, C., Fouquet, Y., 2007. Authigenic carbonates from methane seeps of the Congo deepsea fan. Geo-Mar. Lett. 27, 249-257.

Pierre, C. et al., 2012. Authigenic carbonates from active methane seeps offshore southwest Africa. Geo-Mar Lett. 32, 501-513.

Ristova, P.P., Wenzhofer, F., Ramette, A., Zabel, M., Fischer, D., Kasten, S., Boetius, A., 2012. Bacterial diversity and biogeochemistry of different chemosynthetic habitats of the REGAB cold seep (West African margin, 3160 m water depth). Biogeosciences 9, 50315048.

Riedinger, N., Kasten, S., Groger, J., Franke, C., Pfeifer, K., 2006. Active and buried authigenic barite fronts in sediments from the Eastern Cape Basin. Earth Planet. Sci. Lett. 241, 876-887.

Rongemaille, E., Bayon, G., Pierre, C., Bollinger, C., Chu, N.C., Fouquet, Y., Riboulot, V., Voisset, M., 2011. Rare earth elements in cold seep carbonates from the Niger delta. Chem. Geol. 286, 196-206.

Rousseau, T.C.C., Sonke, J.E., Chmeleff, J., Candaudap, F., Lacan, F., Boaventura, G., Seyler, P., Jeandel, C., 2013. Rare earth element analysis in natural waters by multiple isotope dilution - sector field ICP-MS. J. Anal. Atom. Spectrom. 28, 573-584.

Rue, E.L., Bruland, K.W., 1995. Complexation of iron(III) by natural organic-ligands in the Central North Pacific as determined by a new competitive ligand equilibration adsorptive cathodic stripping voltammetric method. Mar. Chem. 50, 117-138.

Sahling, H., Bohrmann, G., Spiess, V., Bialas, J., Breitzke, M., Ivanov, M., Kasten, S., Krastel, S., Schneider, R., 2008. Pockmarks in the Northern Congo Fan area, SW Africa: Complex seafloor features shaped by fluid flow. Mar. Geol. 249, 206-225.

Saito, M.A., Noble, A.E., Tagliabue, A., Goepfert, T.J., Lamborg, C.H., Jenkins, W.J., 2013. Slow-spreading submarine ridges in the South Atlantic as a significant oceanic iron source. Nat. Geosci. 6, 775-779.

Solomon, E. A., Kastner, M., MacDonald, I. R., Leifer, I. Considerable methane fluxes to the atmosphere from hydrocarbon seeps in the Gulf of Mexico. Nat. Geosci. 2, 561-565 (2009). 
641

642

Sander, S.G., Koschinsky, A., Massoth, G.J., Stott, M., Hunter, K.A., 2007. Organic complexation of copper in deep-sea hydrothermal vent systems. Environ. Chem. 4, 81-89.

Sander, S.G., Koschinsky, A., 2011. Metal flux from hydrothermal vents increased by organic complexation. Nat. Geosci. 4, 145-150.

Sarthou, G., Bucciarelli, E., Chever, F., Hansard, S.P., Gonzalez-Davila, M., SantanaCasiano, J.M., Planchon, F., Speich, S., 2011. Fe(II) concentrations in the Atlantic sector of the Southern Ocean along a transect from the subtropical domain to the Weddell Sea Gyre. Biogeosciences 8, 2461-2479, doi:10.5194/bg-8-2461-2011.

Sauter, E.J., Muyakshin, S.I., Charlou, J.L., Schluter, M., Boetius, A., Jerosch, K., Damm, E., Foucher, J.P., Klages, M., 2006. Methane discharge from a deep-sea submarine mud volcano into the upper water column by gas hydrate-coated methane bubbles. Earth Planet. Sci. Lett. 243, 354-365.

Sherrell, R.M., Field, M.P., Ravizza, G., 1999. Uptake and fractionation of rare earth elements on hydrothermal plume particles at 9 degrees $45^{\prime} \mathrm{N}$, East Pacific Rise. Geochim. Cosmochim. Acta 63, 1709-1722.

Sibuet, M., Olu, K. Biogeography, biodiversity and fluid dependence of deep-sea cold-seep communities at active and passive margins. Deep-Sea Res. II 45, 517-567 (1998).

Statham, P.J., German, C.R., Connelly, D.P., 2005. Iron(II) distribution and oxidation kinetics in hydrothermal plumes at the Kairei and Edmond vent sites, Indian Ocean . Earth Planet. Sci. Lett. 236, 588-596.

Suess, E., 2010. Marine cold seeps. In: Handbook of hydrocarbon and lipid microbiology (Ed. Timmis, K.N.). Springer, Berlin, pp. 188-203.

Tachikawa, K., Toyofuku, T., Basile-Doelsch, I., Delhaye, T., 2013. Microscale neodymium distribution in sedimentary planktonic foraminiferal tests and associated mineral phases. Geochim. Cosmochim. Acta 100, 11-23.

Tagliabue, A., Bopp, L., Dutay, J.C., Bowie, A.R., Chever, F., Jean-Baptiste, P., Bucciarelli, E., Lannuzel, D., Remenyi, T., Sarthou, G., Aumont, O., Gehlen, M., Jeandel, C., 2010. Hydrothermal contribution to the oceanic dissolved iron inventory. Nat. Geosci. 3, 252256. 
682

683

684

685

686

687

688

689

690

691

692

693

694

Toner, B.M., Fakra, S.C., Manganini, S.J., Santelli, C.M., Marcus, M.A., Moffett, J., Rouxel, O., German, C.R., Edwards, K.J., 2009. Preservation of iron(II) by carbon-rich matrices in a hydrothermal plume. Nat. Geosci. 2, 197-201.

Toner, B.M., Marcus, M.A., Edwards, K.J., Rouxel, O., German, C.R., 2012. Measuring the form of iron in hydrothermal plume particles. Oceanography 25, 209-212.

Torres, M.E., McManus, J., Huh, C.A., 2002. Fluid seepage along the San Clemente Fault scarp: basin-wide impact on barium cycling. Earth Planet. Sci. Lett. 203, 181-194.

Vangriesheim, A., Khripounoff, A., Crassous, P., 2009. Turbidity events observed in situ along the Congo submarine channel. Deep-Sea Res. II 56, 2208-2222.

Wallmann, K., Aloisi, G., Haeckel, M., Tishchenko, P., Pavlova, G., Greinert, J., Kutterolf, S., Eisenhauer, A., 2008. Silicate weathering in anoxic marine sediments. Geochim. Cosmochim. Acta 72, 2895-2918.

Wang, H., Yang, Q.H., Ji, F.W., Lilley, M.D., Zhou, H.Y., 2012. The geochemical characteristics and Fe(II) oxidation kinetics of hydrothermal plumes at the Southwest Indian Ridge. Mar. Chem. 134, 29-35.

Westbrook, G.K., et al., 2009. Escape of methane gas from the seabed along the West Spitsbergen continental margin. Geophys. Res. Lett. 36, L15608, doi:10.1029/2009GL039191.

Wu, J.F., 2007. Determination of picomolar iron in seawater by double $\operatorname{Mg}(\mathrm{OH})(2)$ precipitation isotope dilution high-resolution ICPMS. Mar. Chem. 103, 370-381.

Yücel, M., Gartman, A., Chan, C.S., Luther III, G.S., 2011. Hydrothermal vents as a kinetically stable source of iron-sulphide-nearing nanoparticles to the ocean. Nat. Geosci. 4, 367-371. 
696

697

698

699

700

701

702

703

704

705

706

707

708

709

710

711

712

713

714

715

716

717

718

719

720

721

722

723

Figure 1: Location of the Regab and Baboon pockmarks in the Gulf of Guinea. Regab is situated in close proximity to the Congo submarine canyon.

Figure 2: Microbathymetric map of the Regab pockmark showing the location of studied sites and the distribution of seafloor habitats and carbonate-paved areas, as inferred from ROV observations during the WACS cruise (2011). The distribution of methane concentrations in bottom waters ( $+1-2 \mathrm{~m}$ above the seafloor) determined during the ZAI-ROV project (2000) is also shown for comparison (Charlou et al., 2004).

Figure 3: Seafloor bottom photographs of typical seafloor habitats at Regab. A) Mussel (Mytilidae) beds associated with massive carbonate pavements and seafloor gas hydrate deposits in the central part of Regab. B) Details of a mussel field. C) Vesicomyidae field (Clams). D) Methane venting at the Bubble site in the central part of Regab. E) Bushes of vestimentiferan tubeworms (Escarpia southwardae) associated with hard carbonate substrates. F) Seawater sampling (PEPS system) over microbial mats in the southeastern part of the pockmark.

Figure 4: Depth profiles for total dissolvable (TD) and dissolved (DISS) concentrations of $\mathrm{Fe}, \mathrm{Mn}$ and $\mathrm{Nd}$ in unfiltered and filtered seawater samples, respectively.

Figure 5: Shale-normalized (PAAS) REE patterns for unfiltered and filtered seawater samples at the Reference site, and at the Regab (Bubble site and seafloor habitat patches) and Baboon pockmarks. Symbols: unfiltered samples (red circles); filtered samples (white circles). The thick blue line represents the mean shale-normalized REE pattern for the water column at the Reference site (except sample $+1 \mathrm{~m}$ ).

Figure 6: Total dissolvable (TD) Nd versus TDFe concentrations at the Congo seeps. Symbols: Reference and East Pockmark sites (large white diamonds); Bubble site (red squares); seafloor habitat patches (small orange diamonds); Baboon (green triangles). Values for unfiltered seawater samples collected at methane seeps from the Niger Delta margin are shown for comparison (black circles; Bayon et al., 2011a). The trends inferred from our data would be controlled by the presence of Fe-Mn oxyhydroxide phases and easily leachable sulfide minerals in the plume particles. 
724 Figure 7: Relationships between methane and dissolved iron ( $\mathrm{Fe}_{\mathrm{DISS}}$ ) and manganese $725\left(\mathrm{Mn}_{\text {DISS }}\right)$ concentrations in near-seafloor seawater samples at the Congo seeps. The legend for 726 symbols is given in the Fig. 6 caption. 


\section{Figure 1}

Click here to download Figure: Fig1.pdf

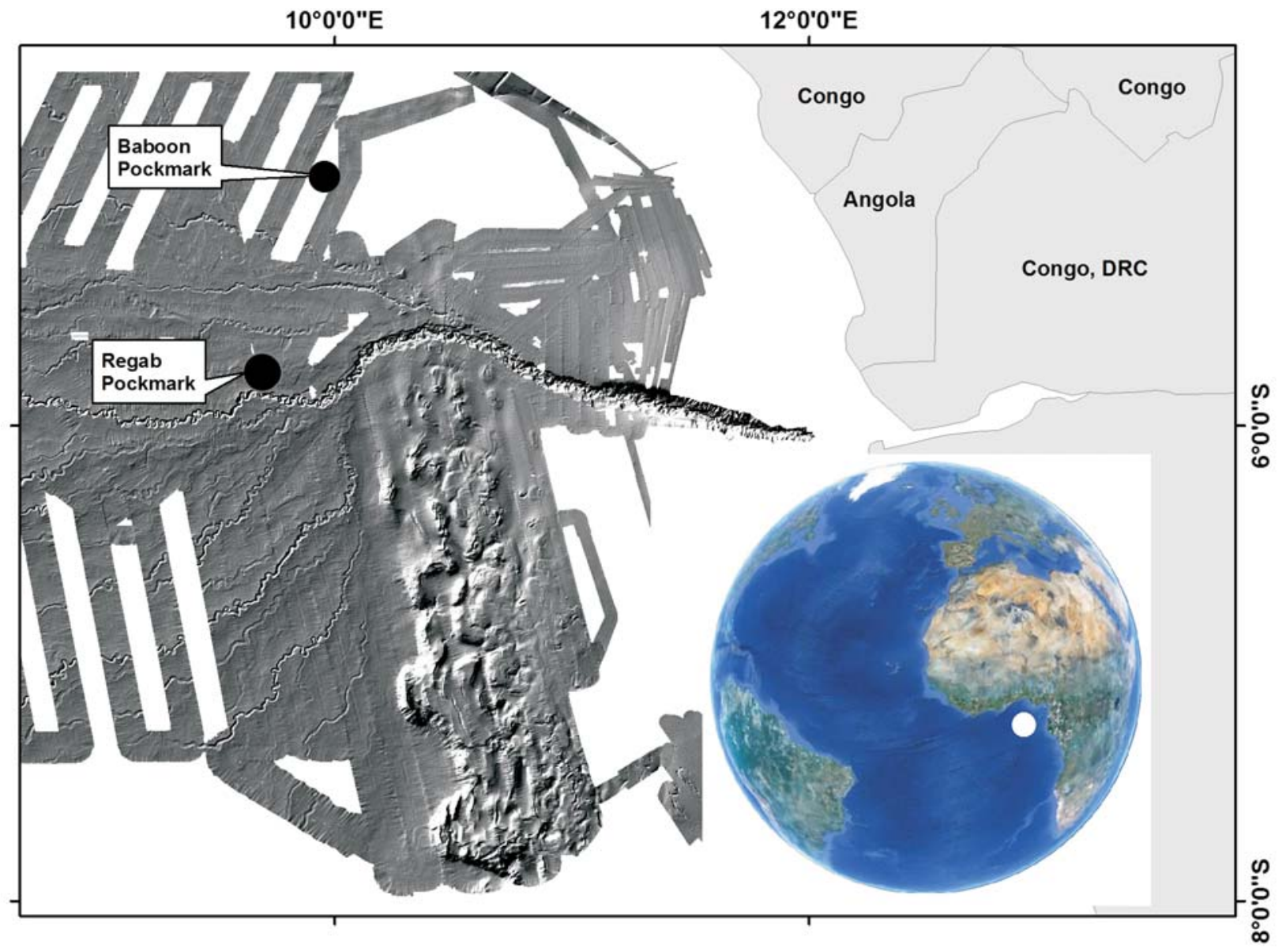

Fig. 1 
Click here to download Figure: Fig2.pdf

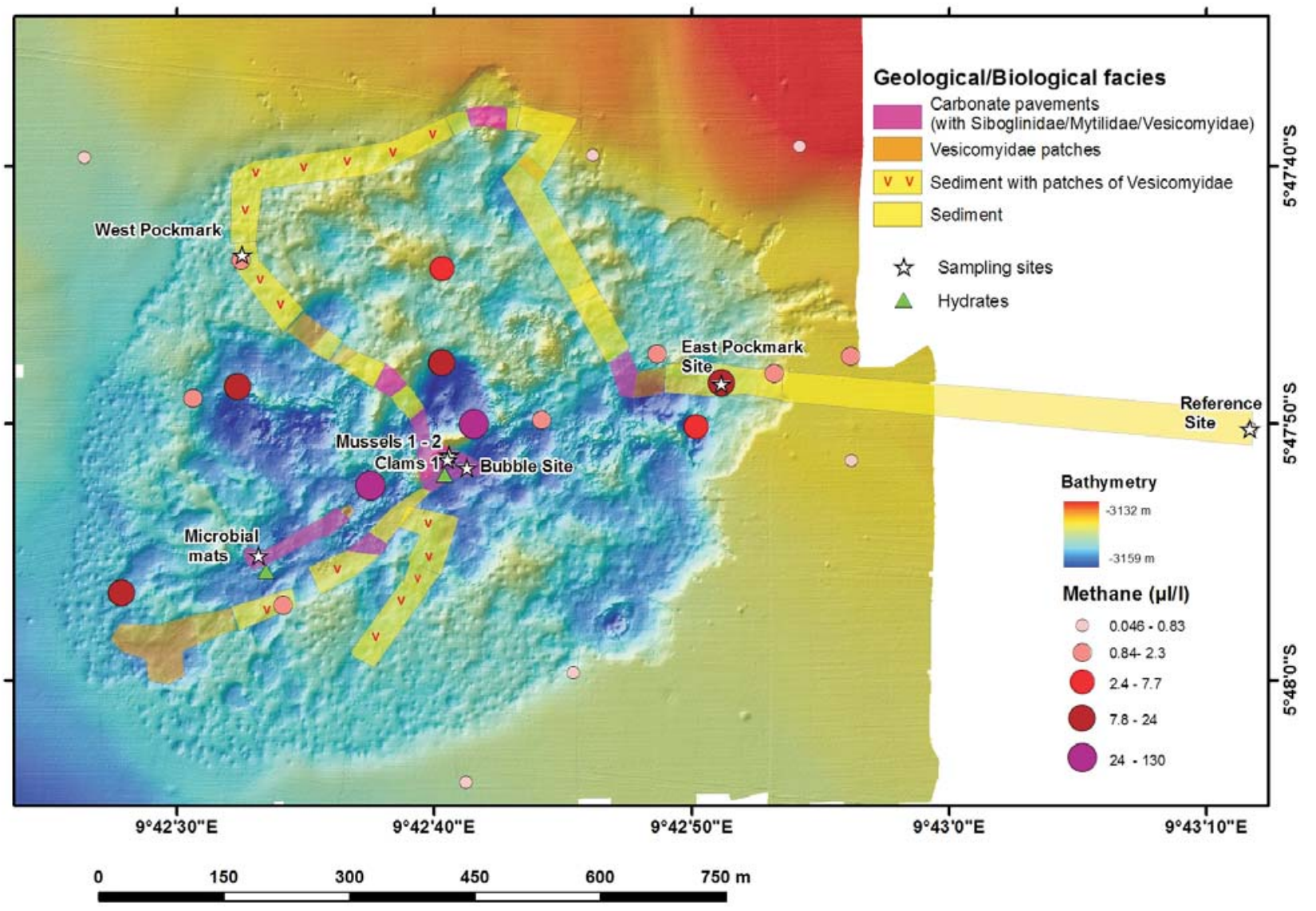

Fig. 2 


\section{Figure3}

Click here to download Figure: Fig3.pdf
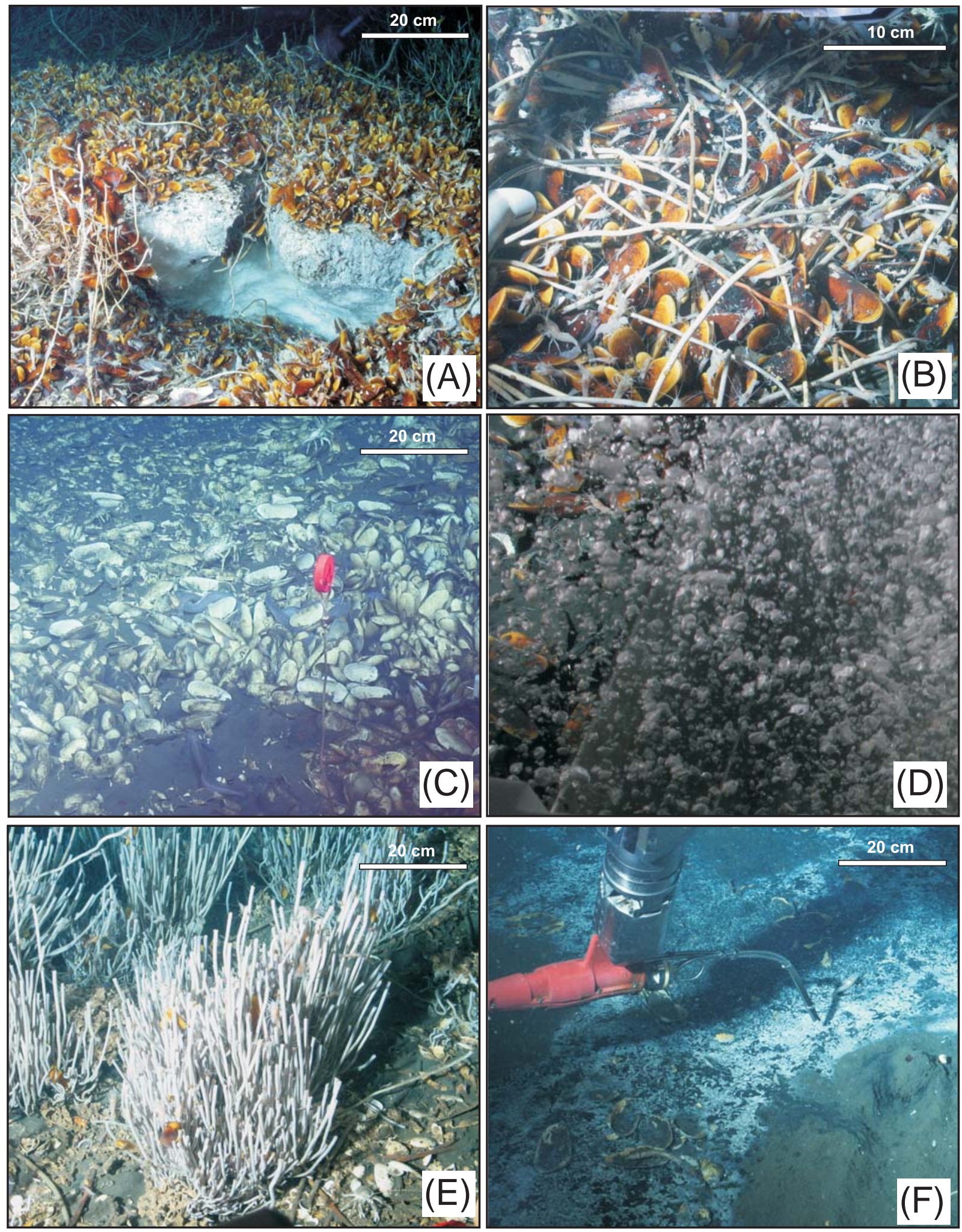

Fig. 3 


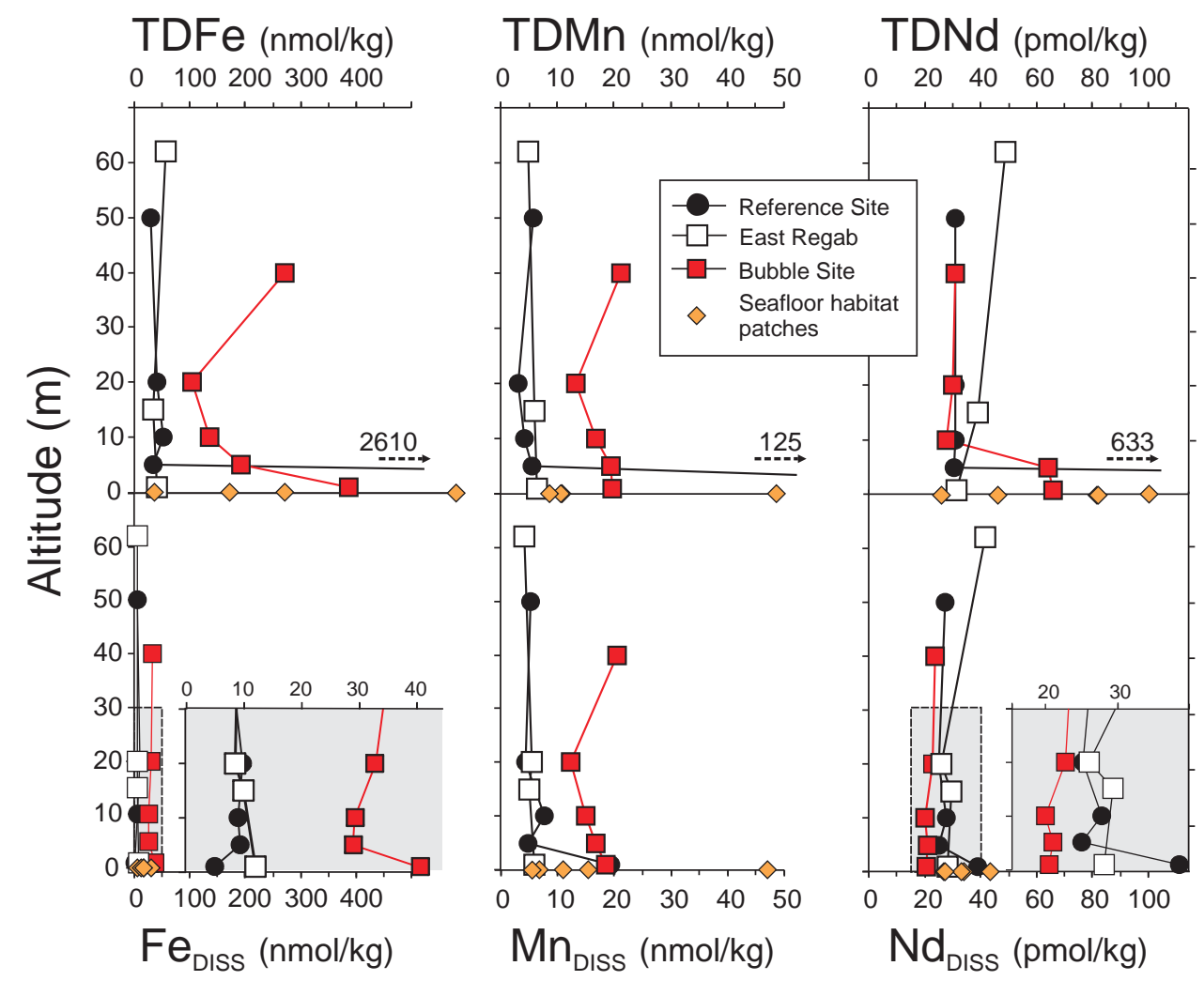

Fig. 4 

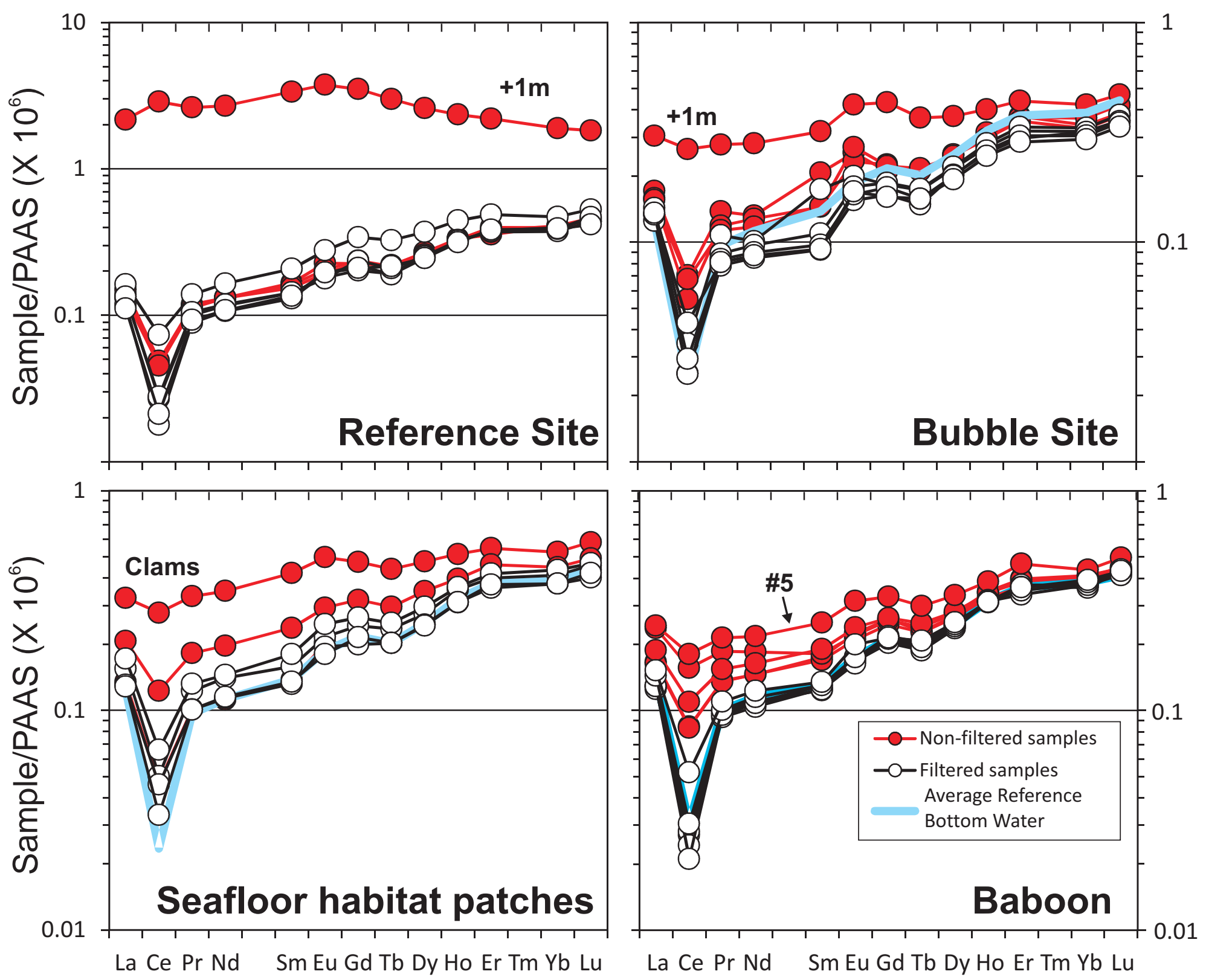

La Ce Pr Nd Sm Eu Gd Tb Dy Ho Er Tm Yb Lu

Fig. 5 


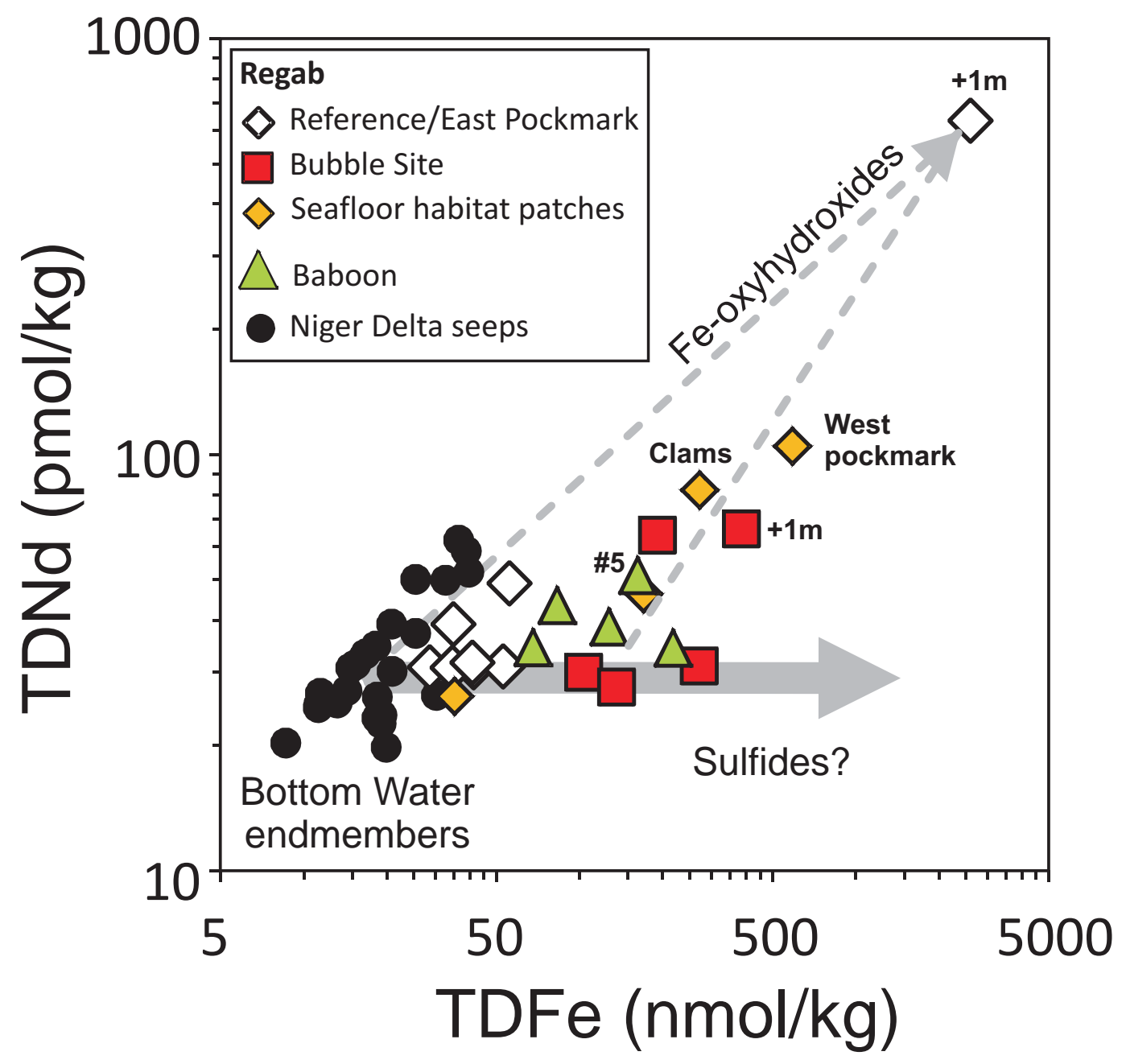

Fig. 6 

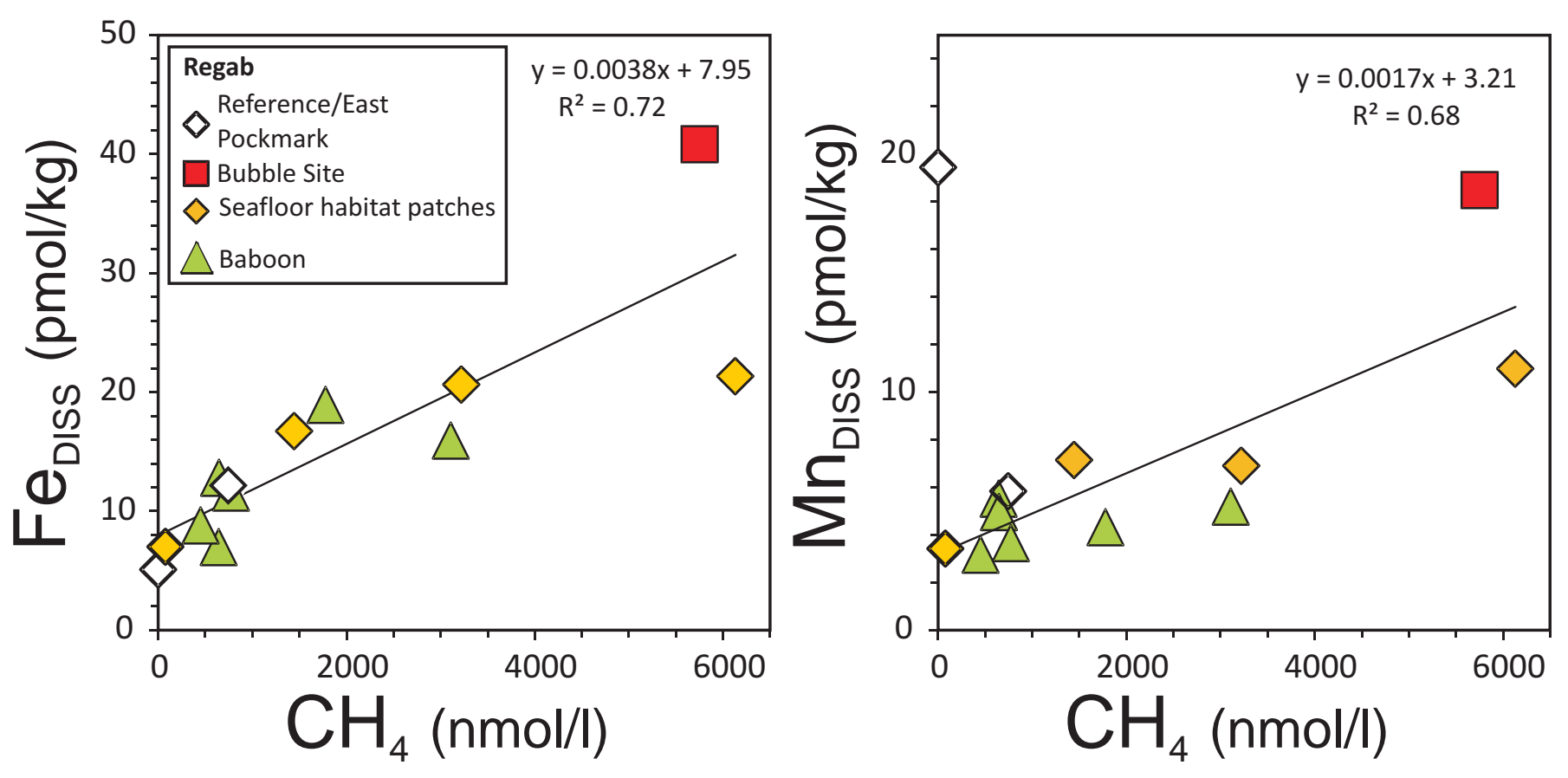

Fig. 7 


\section{Click here to download Table: Table1.pdf}

Table 1

Locations of studied sampling sites at Regab and Baboon pockmarks

\begin{tabular}{|c|c|c|c|c|}
\hline Sampling site & RoV Dive & Latitude & Longitude & Water depth \\
\hline \multicolumn{5}{|l|}{ REGAB } \\
\hline Reference Site & \#429 & $S 5^{\circ} 47,837$ & $E 9^{\circ} 43,195$ & $3145 \mathrm{~m}$ \\
\hline Bubble Site & \#424 & $S 5^{\circ} 47,862$ & E $9^{\circ} 42,688$ & $3156 \mathrm{~m}$ \\
\hline East Pockmark Site & \#429 & $S 5^{\circ} 47,808$ & $E 9^{\circ} 42,852$ & $3150 \mathrm{~m}$ \\
\hline \multicolumn{5}{|c|}{ Seafloor chemosynthetic habitats } \\
\hline West pockmark & \#429 & & & \\
\hline \multicolumn{5}{|l|}{ Mytilidae field (Mussels) } \\
\hline Mussel 1 & \#424 & $S 5^{\circ} 47,854$ & $\mathrm{E} 9^{\circ} 42,676$ & $3152 \mathrm{~m}$ \\
\hline Mussel 2 & \#425 & $S 5^{\circ} 47,853$ & E $9^{\circ} 42,675$ & $3150 \mathrm{~m}$ \\
\hline Vesicomyidae field (Clams) & \#425 & $S 5^{\circ} 47,857$ & $\mathrm{E} 9^{\circ} 42,675$ & $3154 \mathrm{~m}$ \\
\hline Microbial mats & \#427 & $S 5^{\circ} 47,919$ & E $9^{\circ} 42,553$ & $3153 \mathrm{~m}$ \\
\hline \multicolumn{5}{|l|}{ BABOON } \\
\hline$\# 1$ & \#432 & $S 4^{\circ} 56,601$ & E $9^{\circ} 57,338$ & $3047 \mathrm{~m}$ \\
\hline$\# 2$ & \#432 & S $4^{\circ} 56,432$ & E $9^{\circ} 57,088$ & $3040 \mathrm{~m}$ \\
\hline$\# 3$ & \#432 & S $4^{\circ} 56,296$ & E $9^{\circ} 56,984$ & $3035 \mathrm{~m}$ \\
\hline$\# 4$ & \#432 & $S 4^{\circ} 56,238$ & E $9^{\circ} 56,988$ & $3042 \mathrm{~m}$ \\
\hline$\# 5$ & \#432 & S $4^{\circ} 56,195$ & $\mathrm{E} 9^{\circ} 56,975$ & $3046 \mathrm{~m}$ \\
\hline$\# 6$ & $\# 432$ & S $4^{\circ} 56,203$ & $\mathrm{E}^{\circ} 56,961$ & $3047 \mathrm{~m}$ \\
\hline
\end{tabular}


Table 2

Trace element concentrations of non-filtered seawater samples at Regab and Baboon pockmarks.

\begin{tabular}{|c|c|c|c|c|c|c|c|c|c|c|c|c|c|c|c|c|}
\hline & $\begin{array}{l}\text { Mn } \\
\text { (nmol }\end{array}$ & $\begin{array}{c}\mathrm{Fe} \\
\left.\mathbf{k g}^{-1}\right)\end{array}$ & $\begin{array}{c}\mathrm{Y} \\
\text { (pmol }\end{array}$ & $\begin{array}{c}\mathrm{La} \\
\mathrm{kg}^{-1} \text { ) }\end{array}$ & $\begin{array}{l}\text { Ce } \\
\text { (pmol }\end{array}$ & $\begin{array}{c}\mathrm{Pr} \\
\left.\mathbf{k g}^{-1}\right)\end{array}$ & $\begin{array}{l}\text { Nd } \\
\text { (pmol }\end{array}$ & $\begin{array}{c}\mathrm{Sm} \\
\left.\mathrm{kg}^{-1}\right)\end{array}$ & $\begin{array}{l}\text { Eu } \\
\text { (pmol }\end{array}$ & $\begin{array}{c}\mathbf{G d} \\
\left(\mathbf{k g}^{-1}\right)\end{array}$ & $\begin{array}{l}\text { Tb } \\
\text { (pmol }\end{array}$ & $\begin{array}{c}\text { Dy } \\
\left(\mathbf{k g}^{-1}\right)\end{array}$ & $\begin{array}{l}\text { Ho } \\
\text { (pmol I }\end{array}$ & $\begin{array}{c}\mathrm{Er} \\
\left.\mathrm{kg}^{-1}\right)\end{array}$ & $\begin{array}{l}\text { Yb } \\
\text { (pmol }\end{array}$ & $\begin{array}{c}\mathrm{Lu} \\
\left(\mathrm{kg}^{-1}\right)\end{array}$ \\
\hline \multicolumn{17}{|c|}{ REGAB } \\
\hline $50 \mathrm{~m}$ & 5.7 & 29 & 180 & 41 & 28 & 7.2 & 31 & 6.0 & 1.45 & 7.0 & 1.05 & 7.8 & 1.97 & 6.8 & 6.5 & 1.09 \\
\hline $20 \mathrm{~m}$ & 3.0 & 41 & 151 & 36 & 26 & 7.0 & 31 & 5.7 & 1.37 & 6.8 & 1.06 & 7.5 & 2.00 & 6.1 & 6.7 & 1.07 \\
\hline $10 \mathrm{~m}$ & 4.1 & 53 & 157 & 38 & 26 & 7.4 & 31 & 6.1 & 1.61 & 6.7 & 1.07 & 7.7 & 2.00 & 6.5 & 6.6 & 1.14 \\
\hline $5 \mathrm{~m}$ & 5.4 & 35 & 162 & 36 & 20 & 7.2 & 31 & 5.9 & 1.57 & 7.0 & 1.06 & 7.6 & 1.99 & 6.4 & 6.3 & 1.14 \\
\hline $1 \mathrm{~m}$ & 125 & 2610 & 662 & 595 & 1632 & 164 & 633 & 124 & 27 & 104 & 14.6 & 75 & 14.1 & 37 & 31 & 4.5 \\
\hline \multicolumn{17}{|l|}{ Bubble Site } \\
\hline $40 \mathrm{~m}$ & 21 & 272 & 187 & 47 & 40 & 8.6 & 31 & 7.6 & 1.81 & 6.2 & 1.03 & 7.2 & 1.76 & 6.4 & 5.6 & 0.95 \\
\hline $20 \mathrm{~m}$ & 13 & 104 & 197 & 44 & 31 & 7.4 & 30 & 5.3 & 1.66 & 6.7 & 1.02 & 7.2 & 1.89 & 6.3 & 6.0 & 1.04 \\
\hline $10 \mathrm{~m}$ & 17 & 137 & 192 & 43 & 38 & 7.1 & 28 & 5.4 & 1.92 & 6.6 & 1.05 & 7.1 & 1.78 & 6.0 & 5.4 & 0.93 \\
\hline $5 \mathrm{~m}$ & 19 & 192 & 204 & 135 & 182 & 21 & 64 & 6.1 & 1.83 & 7.9 & 1.13 & 7.7 & 1.89 & 6.0 & 5.8 & 0.97 \\
\hline $1 \mathrm{~m}$ & 20 & 386 & 221 & 84 & 150 & 17 & 66 & 11.8 & 3.00 & 12.8 & 1.79 & 10.8 & 2.42 & 7.5 & 6.9 & 1.16 \\
\hline \multicolumn{17}{|c|}{ East Pockmark Site } \\
\hline $62 \mathrm{~m}$ & 4.8 & 56 & 213 & 66 & 95 & 12.8 & 49 & 9.0 & 2.16 & 9.8 & 1.48 & 9.5 & 2.33 & 7.4 & 6.8 & 1.13 \\
\hline $15 \mathrm{~m}$ & 6.1 & 35 & 232 & 48 & 27 & 8.9 & 39 & 7.4 & 1.98 & 9.1 & 1.35 & 9.5 & 2.60 & 8.0 & 8.3 & 1.31 \\
\hline $1 \mathrm{~m}$ & 6.3 & 41 & 169 & 41 & 30 & 7.6 & 32 & 5.9 & 1.58 & 7.2 & 1.08 & 7.3 & 1.89 & 5.9 & 5.9 & 1.01 \\
\hline \multicolumn{17}{|c|}{$\begin{array}{l}\text { Seafloor chemosynthetic habitats } \\
\text { West Pockmark }\end{array}$} \\
\hline $1 \mathrm{~m}$ & 6.7 & 592 & 228 & 110 & 173 & 26.1 & 104 & 19.9 & 4.22 & 19.5 & 2.83 & 14.8 & 3.60 & 9.4 & 9.1 & 1.45 \\
\hline \multicolumn{17}{|c|}{ Mytilidae field (Mussels) } \\
\hline \#1 (0.1 m) & 49 & 35 & 186 & 37 & 26 & 6.4 & 26 & 5.1 & 1.43 & 6.1 & 0.99 & 7.1 & 1.86 & 6.3 & 6.4 & 1.08 \\
\hline \#2 (0.1 m) & 8.6 & 171 & 221 & 57 & 70 & 11.4 & 46 & 8.7 & 2.08 & 9.4 & 1.44 & 10.0 & 2.38 & 7.8 & 7.3 & 1.21 \\
\hline \multicolumn{17}{|c|}{ Vesicomyidae field (Clams) } \\
\hline $0.1 \mathrm{~m}$ & 10.7 & 273 & 230 & 89 & 158 & 21 & 82 & 16 & 3.53 & 14.0 & 2.14 & 13.7 & 3.08 & 9.3 & 8.6 & 1.44 \\
\hline \multicolumn{17}{|l|}{ BABOON } \\
\hline \#1 (3 m) & 6.7 & 219 & 196 & 46 & 48 & 8.6 & 34 & 6.5 & 1.60 & 7.7 & 1.11 & 7.8 & 2.06 & 6.5 & 6.6 & 1.06 \\
\hline \#2 (3 m) & 5.3 & 68 & 195 & 45 & 47 & 8.5 & 34 & 6.3 & 1.49 & 7.3 & 1.10 & 7.6 & 1.97 & 6.2 & 6.1 & 1.07 \\
\hline \#3 (3 m) & 4.8 & 83 & 204 & 65 & 89 & 11.7 & 43 & 6.7 & 1.57 & 7.6 & 1.17 & 8.0 & 2.09 & 6.8 & 6.7 & 1.10 \\
\hline$\# 4$ (3 m) & 4.3 & 128 & 203 & 52 & 62 & 9.7 & 38 & 7.0 & 1.70 & 7.8 & 1.21 & 8.1 & 2.05 & 6.7 & 6.6 & 1.11 \\
\hline \#5 (3 m) & 4.0 & 163 & 215 & 67 & 103 & 13.4 & 51 & 9.3 & 2.24 & 9.8 & 1.45 & 9.6 & 2.32 & 7.9 & 7.1 & 1.23 \\
\hline \#6 (3 m) & 6.8 & 287 & - & - & - & - & - & - & - & - & - & - & - & - & - & - \\
\hline
\end{tabular}


Table 3

Trace element concentrations of filtered seawater samples at Regab and Baboon pockmarks.

\begin{tabular}{|c|c|c|c|c|c|c|c|c|c|c|c|c|c|c|c|c|}
\hline $\begin{array}{l}\text { Altitude } \\
\text { (m) }\end{array}$ & $\begin{array}{l}\text { Mn } \\
\text { (nmol r }\end{array}$ & $\begin{array}{l}\mathrm{Fe} \\
\left.\mathrm{kg}^{-1}\right)\end{array}$ & $\begin{array}{c}\mathrm{Y} \\
(\mathrm{pmol}\end{array}$ & $\begin{array}{l}\mathrm{La} \\
\left.\mathbf{k g}^{-1}\right)\end{array}$ & $\begin{array}{l}\mathrm{Ce} \\
(\mathrm{pmol} \mathrm{k}\end{array}$ & $\begin{array}{c}\mathrm{Pr} \\
\left.\mathrm{kg}^{-1}\right)\end{array}$ & $\begin{array}{l}\text { Nd } \\
(p m o l\end{array}$ & $\begin{array}{l}\mathrm{Sm} \\
\left.\mathrm{kg}^{-1}\right)\end{array}$ & $\begin{array}{l}\text { Eu } \\
(p m o l\end{array}$ & $\begin{array}{l}\mathbf{G d} \\
\left.\mathbf{k g}^{-1}\right)\end{array}$ & $\begin{array}{l}\text { Tb } \\
\text { (pmol }\end{array}$ & $\begin{array}{c}\text { Dy } \\
\left.\mathbf{k g}^{-1}\right)\end{array}$ & $\begin{array}{l}\text { Ho } \\
\text { (pmol I }\end{array}$ & $\begin{array}{c}\mathrm{Er} \\
\left.\mathbf{k g}^{-1}\right)\end{array}$ & $\begin{array}{l}\text { Yb } \\
(p m o l\end{array}$ & $\begin{array}{l}\mathrm{Lu} \\
\left.\mathrm{kg}^{-1}\right)\end{array}$ \\
\hline \multicolumn{17}{|c|}{ Reference Site } \\
\hline $50 \mathrm{~m}$ & 5.3 & 8.0 & 175 & 37 & 15 & 6.3 & 27 & 5.2 & 1.28 & 6.0 & 0.94 & 7.3 & 1.92 & 6.4 & 6.5 & 1.11 \\
\hline $20 \mathrm{~m}$ & 5.6 & 10.0 & 153 & 31 & 12 & 5.8 & 25 & 5.0 & 1.39 & 6.2 & 1.05 & 7.1 & 1.89 & 6.5 & 6.4 & 1.03 \\
\hline $10 \mathrm{~m}$ & 7.7 & 9.2 & 166 & 37 & 16 & 6.6 & 28 & 5.3 & 1.27 & 7.0 & 1.02 & 7.2 & 1.93 & 6.4 & 6.3 & 1.16 \\
\hline $5 \mathrm{~m}$ & 7.0 & 9.5 & 164 & 32 & 10 & 5.6 & 25 & 4.8 & 1.37 & 6.5 & 0.92 & 7.1 & 1.96 & 6.3 & 6.1 & 1.07 \\
\hline $1 \mathrm{~m}$ & 19 & 5.1 & 196 & 45 & 42 & 8.7 & 39 & 7.7 & 1.97 & 10.1 & 1.58 & 10.6 & 2.67 & 8.3 & 7.7 & 1.30 \\
\hline \multicolumn{17}{|l|}{ Bubble Site } \\
\hline $40 \mathrm{~m}$ & 21 & 36 & 176 & 39 & 20 & 6.7 & 24 & 6.4 & 1.42 & 5.4 & 0.84 & 6.2 & 1.63 & 5.5 & 5.2 & 0.88 \\
\hline $20 \mathrm{~m}$ & 12 & 33 & 184 & 37 & 14 & 5.6 & 23 & 4.0 & 1.27 & 5.5 & 0.85 & 6.3 & 1.69 & 5.7 & 5.4 & 0.94 \\
\hline $10 \mathrm{~m}$ & 15 & 30 & 180 & 34 & 14 & 4.9 & 20 & 3.4 & 1.10 & 4.9 & 0.72 & 5.8 & 1.53 & 5.1 & 5.2 & 0.88 \\
\hline $5 \mathrm{~m}$ & 17 & 29 & 182 & 37 & 17 & 5.2 & 21 & 3.6 & 1.17 & 5.2 & 0.77 & 5.8 & 1.57 & 5.2 & 5.0 & 0.86 \\
\hline $1 \mathrm{~m}$ & 18 & 41 & 173 & 37 & 24 & 5.1 & 20 & 3.4 & 1.21 & 4.8 & 0.77 & 5.6 & 1.48 & 4.9 & 4.8 & 0.83 \\
\hline \multicolumn{17}{|c|}{ East Pockmark Site } \\
\hline $62 \mathrm{~m}$ & 4.2 & 8.5 & 209 & 55 & 65 & 10.4 & 42 & 7.7 & 1.87 & 8.6 & 1.25 & 8.7 & 2.18 & 6.8 & 6.6 & 1.10 \\
\hline $20 \mathrm{~m}$ & 5.5 & 8.7 & 200 & 39 & 18 & 6.4 & 26 & 4.8 & 1.25 & 6.5 & 0.97 & 7.4 & 1.86 & 5.7 & 6.0 & 0.99 \\
\hline $15 \mathrm{~m}$ & 5.0 & 10.1 & 207 & 39 & 12 & 7.4 & 29 & 5.4 & 1.46 & 7.5 & 1.24 & 8.4 & 2.14 & 7.0 & 7.5 & 1.25 \\
\hline $1 \mathrm{~m}$ & 5.8 & 12.2 & 167 & 38 & 20 & 6.8 & 28 & 5.5 & 1.20 & 7.1 & 0.98 & 6.8 & 1.71 & 5.9 & 5.7 & 0.96 \\
\hline \multicolumn{17}{|c|}{$\begin{array}{l}\text { Seafloor chemosynthetic habitats } \\
\text { West Pockmark }\end{array}$} \\
\hline $1 \mathrm{~m}$ & 4.4 & 7.0 & 165 & 34 & 15 & 6.3 & 26 & 4.8 & 1.25 & 6.3 & 1.04 & 6.8 & 1.80 & 6.2 & 5.8 & 1.04 \\
\hline \multicolumn{17}{|c|}{ Mytilidae field (Mussels) } \\
\hline \#1 (0.1 m) & 47 & 34 & 180 & 36 & 26 & 6.3 & 27 & 4.9 & 1.38 & 5.9 & 0.98 & 7.1 & 1.86 & 6.1 & 6.1 & 0.99 \\
\hline \#2 (0.1 m) & 6.9 & 21 & 180 & 35 & 19 & 6.3 & 27 & 5.0 & 1.28 & 6.4 & 0.99 & 7.0 & 1.86 & 6.4 & 6.1 & 1.04 \\
\hline \multicolumn{17}{|c|}{ Vesicomyidae field (Clams) } \\
\hline $0.1 \mathrm{~m}$ & 11.0 & 21 & 201 & 47 & 37 & 8.3 & 34 & 6.6 & 1.75 & 7.8 & 1.22 & 8.5 & 2.18 & 7.1 & 7.1 & 1.15 \\
\hline \multicolumn{17}{|c|}{ Microbial mats } \\
\hline $0.1 \mathrm{~m}$ & 7.1 & 17 & 188 & 43 & 28 & 7.7 & 33 & 5.8 & 1.53 & 7.2 & 1.14 & 7.9 & 2.12 & 6.8 & 6.7 & 1.13 \\
\hline \multicolumn{17}{|l|}{ BABOON } \\
\hline$\# 1$ (3 m) & 5.5 & 7.0 & 195 & 36 & 15 & 6.1 & 26 & 4.8 & 1.24 & 6.1 & 0.93 & 7.0 & 1.86 & 6.3 & 5.9 & 1.07 \\
\hline \#2 (3 m) & 5.0 & 12.8 & 182 & 34 & 16 & 5.8 & 24 & 4.6 & 1.19 & 6.0 & 0.91 & 6.8 & 1.89 & 5.7 & 6.1 & 1.02 \\
\hline \#3 (3 m) & 4.3 & 18.9 & 196 & 35 & 14 & 6.3 & 26 & 4.6 & 1.23 & 6.5 & 0.99 & 7.0 & 1.91 & 6.0 & 6.2 & 1.05 \\
\hline \#4 (3 m) & 3.7 & 11.6 & 194 & 35 & 12 & 6.0 & 25 & 4.6 & 1.16 & 6.3 & 0.98 & 6.9 & 1.87 & 6.4 & 6.1 & 1.08 \\
\hline \#5 (3 m) & 3.2 & 8.8 & 194 & 40 & 17 & 6.3 & 27 & 4.8 & 1.24 & 6.3 & 0.94 & 7.1 & 1.89 & 6.2 & 6.2 & 1.02 \\
\hline \#6 (3 m) & 5.2 & 15.9 & 196 & 42 & 30 & 6.9 & 29 & 5.0 & 1.42 & 6.3 & 1.01 & 7.2 & 1.87 & 6.2 & 6.4 & 1.07 \\
\hline
\end{tabular}


Table S1

Trace element concentrations of certified reference materials used in this study.

\begin{tabular}{|c|c|c|c|c|c|c|c|c|c|c|c|c|c|c|c|c|}
\hline & $\begin{array}{l}\mathrm{Mn} \\
(\mu \mathrm{g} \mathrm{kg}\end{array}$ & $\begin{array}{c}\mathrm{Fe} \\
\left.\mathrm{g}^{-1}\right)\end{array}$ & $\begin{array}{l}\text { Y } \\
\text { (ng kg }\end{array}$ & $\begin{array}{l}\mathrm{La} \\
\left.g^{-1}\right)\end{array}$ & $\begin{array}{l}\text { Ce } \\
\text { (ng kg }\end{array}$ & $\begin{array}{r}\mathrm{Pr} \\
\left.g^{-1}\right)\end{array}$ & $\begin{array}{l}\text { Nd } \\
\text { (ng kd }\end{array}$ & $\underset{\left(g^{-1}\right)}{S m}$ & $\begin{array}{l}\text { Eu } \\
\text { (ng kg }\end{array}$ & $\begin{array}{c}\text { Gd } \\
\left(g^{-1}\right)\end{array}$ & $\begin{array}{l}\text { Tb } \\
\text { (ng kg }\end{array}$ & $\begin{array}{l}\text { Dy } \\
\left(g^{-1}\right)\end{array}$ & $\begin{array}{l}\text { Ho } \\
\text { (ng ks }\end{array}$ & $\begin{array}{l}\mathrm{Er} \\
\left.\mathrm{g}^{-1}\right)\end{array}$ & $\begin{array}{l}\text { Yb } \\
\text { (ng ks }\end{array}$ & $\begin{array}{l}\text { Lu } \\
\left(g^{-1}\right)\end{array}$ \\
\hline \multicolumn{17}{|l|}{ NASS-6 $(n=11)$} \\
\hline mean & 0.50 & 0.48 & 23.1 & 9.87 & 3.64 & 1.50 & 6.40 & 1.13 & 0.24 & 1.51 & 0.22 & 1.61 & 0.42 & 1.35 & 1.30 & 0.22 \\
\hline & 0.09 & 0.07 & 2.7 & 0.89 & 0.54 & 0.10 & 0.26 & 0.05 & 0.01 & 0.08 & 0.01 & 0.07 & 0.02 & 0.03 & 0.06 & 0.01 \\
\hline certified & 0.52 & 0.48 & & & & & & & & & & & & & & \\
\hline deviation ( & 3.4 & 0.2 & & & & & & & & & & & & & & \\
\hline RSD (\%) & 18.9 & 15.6 & 11.7 & 9.1 & 14.7 & 6.4 & 4.1 & 4.1 & 3.6 & 5.4 & 3.4 & 4.1 & 4.4 & 2.4 & 4.3 & 5.6 \\
\hline \multicolumn{17}{|l|}{ CASS-5 $(n=12)$} \\
\hline mean & 2.41 & 1.44 & 20.1 & 7.94 & 3.44 & 1.17 & 5.02 & 1.24 & 0.20 & 1.29 & 0.18 & 1.31 & 0.34 & 1.12 & 1.09 & 0.18 \\
\hline $\mathrm{s}$ & 0.41 & 0.02 & 2.6 & 0.85 & 0.55 & 0.09 & 0.23 & 0.05 & 0.01 & 0.06 & 0.01 & 0.07 & 0.01 & 0.03 & 0.02 & 0.01 \\
\hline certified & 2.56 & 1.4 & & 7.95 & 3.36 & 1.16 & 5.02 & 1.22 & 0.2 & 1.21 & 0.17 & 1.23 & 0.32 & 1.07 & 1.08 & 0.19 \\
\hline deviatior & -6.4 & 3.1 & & -0.1 & 2.3 & 1.0 & 0.0 & 2.3 & -1.3 & 6.4 & 3.0 & 6.3 & 8.6 & 5.1 & 0.6 & -2.3 \\
\hline RSD (\%) & 16.9 & 1.4 & 12.9 & 10.6 & 16.0 & 7.3 & 4.7 & 3.8 & 4.6 & 5.0 & 4.0 & 5.3 & 3.0 & 3.0 & 2.0 & 3.5 \\
\hline \multicolumn{17}{|c|}{ In-house seawater standard - Concarneau Bay $(n=4)$} \\
\hline mean & 0.04 & 0.15 & 17.1 & 1.98 & 1.54 & 0.63 & 3.10 & 0.74 & 0.21 & 1.24 & 0.20 & 1.39 & 0.35 & 1.13 & 1.08 & 0.17 \\
\hline $\begin{array}{r}\mathrm{S} \\
\text { certified } \\
\text { deviation }(\%)\end{array}$ & 0.01 & 0.05 & 1.9 & 0.25 & 0.38 & 0.04 & 0.12 & 0.04 & 0.01 & 0.10 & 0.01 & 0.07 & 0.02 & 0.03 & 0.01 & 0.00 \\
\hline RSD (\%) & 29.6 & 33.5 & 11.1 & 12.5 & 24.4 & 5.8 & 3.9 & 5.5 & 4.3 & 8.3 & 5.1 & 5.1 & 6.0 & 2.7 & 0.2 & 0.7 \\
\hline
\end{tabular}


Click here to download Table: TableS2.pdf

Table S2

Methane, $\mathrm{Fe}_{\mathrm{DISS}}$ and $\mathrm{Mn}_{\mathrm{DISS}}$ concentrations at the Congo seeps

\begin{tabular}{|c|c|c|c|c|c|}
\hline Sampling site & $\begin{array}{l}\text { Altitude } \\
\text { (m) }\end{array}$ & $\begin{array}{l}\mathrm{CH}_{4} \\
(\mu \mathrm{I} / \mathrm{I})\end{array}$ & $\begin{array}{c}\mathrm{CH}_{4} \\
\text { (nmol/l) }\end{array}$ & $\begin{array}{c}\mathrm{Mn}_{\text {DIss }} \\
\text { (nmol/kg) }\end{array}$ & $\begin{array}{c}\mathrm{Fe}_{\text {DIss }} \\
(\mathrm{nmol} / \mathrm{kg})\end{array}$ \\
\hline \multicolumn{6}{|l|}{ REGAB } \\
\hline Reference Site & $+1 \mathrm{~m}$ & $0.046^{\mathrm{a}}$ & 2 & 19.4 & 5.1 \\
\hline Bubble Site & $+1 \mathrm{~m}$ & $128.9^{\mathrm{a}}$ & 5755 & 18.5 & 40.8 \\
\hline East Pockmark Site & $+1 \mathrm{~m}$ & $16.7^{\mathrm{a}}$ & 745 & 5.8 & 12.2 \\
\hline \multicolumn{6}{|c|}{ Seafloor chemosynthetic habitats } \\
\hline West pockmark & $+1 \mathrm{~m}$ & $1.8^{\mathrm{a}}$ & 80 & 4.3 & 7.0 \\
\hline Mytilidae field (Mussel 2) & $+0.1 \mathrm{~m}$ & $72.2^{\mathrm{b}}$ & 3223 & 6.9 & 20.6 \\
\hline Vesicomyidae field (Clams) & $+0.1 \mathrm{~m}$ & $137.4^{\mathrm{b}}$ & 6134 & 11.0 & 21.3 \\
\hline Microbial mats & $+0.1 \mathrm{~m}$ & $32.4^{\mathrm{b}}$ & 1446 & 7.1 & 16.7 \\
\hline \multicolumn{6}{|l|}{ BABOON } \\
\hline$\# 1$ & $+3 m$ & $14.5^{\mathrm{b}}$ & 647 & 5.5 & 7.0 \\
\hline \#2 & $+3 m$ & $14.6^{\mathrm{b}}$ & 652 & 5.0 & 12.8 \\
\hline$\# 3$ & $+3 m$ & $39.9^{b}$ & 1781 & 4.3 & 18.9 \\
\hline$\# 4$ & $+3 m$ & $17.4^{\mathrm{b}}$ & 777 & 3.7 & 11.6 \\
\hline$\# 5$ & $+3 m$ & $10.2^{b}$ & 455 & 3.2 & 8.8 \\
\hline$\# 6$ & $+3 m$ & $69.7^{\mathrm{D}}$ & 3112 & 5.2 & 15.9 \\
\hline
\end{tabular}

${ }^{\text {a }}$ Charlou et al. (2004); ${ }^{\mathrm{b}}$ This study 